\title{
THE DYNAMICS OF THE AMERY ICE SHELF
}

\author{
By W. BudD* \\ (Meteorology Department, University of Melbourne, Parkville, Victoria, Australia)
}

\begin{abstract}
A general survey of the preliminary results of a three-year program of measurements on the Amery Ice Shelf by A.N.A.R.E. are presented, together with theoretical considerations of the velocity and stress distributions and the mass and energy regimes of the ice shelf.

In order to explain the observed velocity distribution it has been found necessary to extend Weertman's theory of ice-shelf creep to an ice shelf bounded at its sides. The resulting theoretical velocity profile applied to the results of the Amery Ice Shelf provides estimates of the average values of the power flow-law parameters for the ice shelf.

The energy and mass budget considerations, together with the recorded change in form of the ice front, suggest that the ice-shelf regime is not in a continual state of balance but may fluctuate as the ice shelf changes in form over a period of about forty years.
\end{abstract}

RÉsumé. Dynamique de l'Amery Ice Shelf, Antarctique. Un aperçu général des résultats préliminaires d'un programme triennal de mesures de l'Amery Ice Shelf par A.N.A.R.E. est présenté, en même temps que des considérations théoriques sur les distributions des vitesses et des contraintes et des bilans de masse et d'énergie de l'ice shelf.

Pour expliquer la distribution des vitesses observée, il a été trouvé nécessaire d'étendre la théorie de Weertman sur le fluage d'un ice shelf à celui d'un ice shelf fixé sur ses cotés. Le profil théorique des vitesses qui en résulte, appliqué aux résultats obtenus sur l'Amery Ice Shelf, donne des estimations des valeurs moyennes des paramètres de la loi de puissance de l'écoulement pour l'ice shelf.

Les considérations sur le bilan de masse et d'énergie, en même temps que le changement observé de la forme du front de la glace, suggèrent que le régime de l'ice shelf n'est pas dans un état continu d'équilibre, mais qu'il peut varier quand l'ice shelf change dans sa forme pendant une période d'environ quarante ans.

Zusammenfassung. Die Dynamik des Amery-Eisschelfs, Antarklika. Es wird eine Gesamtübersicht über die vorläufigen Ergebnisse eines dreijährigen Messprogramms der A.N.A.R.E. auf dem Amery-Eisschelf zusammen mit theoretischen Betrachtungen über die Geschwindigkeits- und Spannungsverteilung, sowie über Massen- und Energiehaushalt des Eisschelfs vorgelegt.

Um die beobachtete Geschwindigkeitsverteilung zu erklären, war es nötig, die Weertman'sche Theorie der Eisschelfbewegung auf ein seitlich begrenztes Eisschelf zu erweitern. Das sich ergebende theoretische Geschwindigkeitsprofil, angewandt auf die Ergebnisse vom Amery-Eisschelf, liefert Näherungswerte für die mittleren Parameterwerte des experimentellen Fliessgesetzes für das Eisschelf.

Die Überlegungen zum Energie- und Massenhaushalt lassen zusammen mit der bisher bekannten FormVeränderung der Eisfront vermuten, dass der Haushalt des Eisschelfs nicht in dauerndem Gleichgewicht ist, sondern vermutlich wie die Formveränderungen des Eisschelfs mit einer Periode von etwa 40 Jahren schwankt.

\section{INTRODU GTION}

Since 1962 the Australian National Antarctic Research Expeditions have travelled to the Amery Ice Shelf, from Mawson, each summer to carry out a program of measurements. The routes travelled, the measurements carried out and the methods used have been discussed by Landon-Smith ([ 1964$]$, unpublished) and Budd (1965). The route travelled in $1_{96} 3$ and 1964 is shown in Fig. I. The general results of the preliminary analysis of the measurements of elevation and slope, velocity, strain-rate, accumulation, and surface temperature, over the ice shelf are shown in Table I and Figures 2 to 8 . Further results calculated from these are shown in Table II. A detailed presentation of the measurements is in preparation. The purpose of this paper is to present the general form of the results together with theoretical considerations of their import.

\section{Discussion of Results of Measurements}

\section{I. Surface slope and ice thickness}

The Amery Ice Shelf is comparatively flat with surface slope increasing gradually from $0.3 \times \mathrm{IO}^{-4}$ at the front to $\mathrm{I} .2 \times \mathrm{IO}^{-4}$ at G3, then more rapidly to $2.0 \times \mathrm{IO}^{-4}$ where the Lambert

* Antarctic Division, Department of External Affairs, Australia, attached to the Meteorology Department, University of Melbourne. 


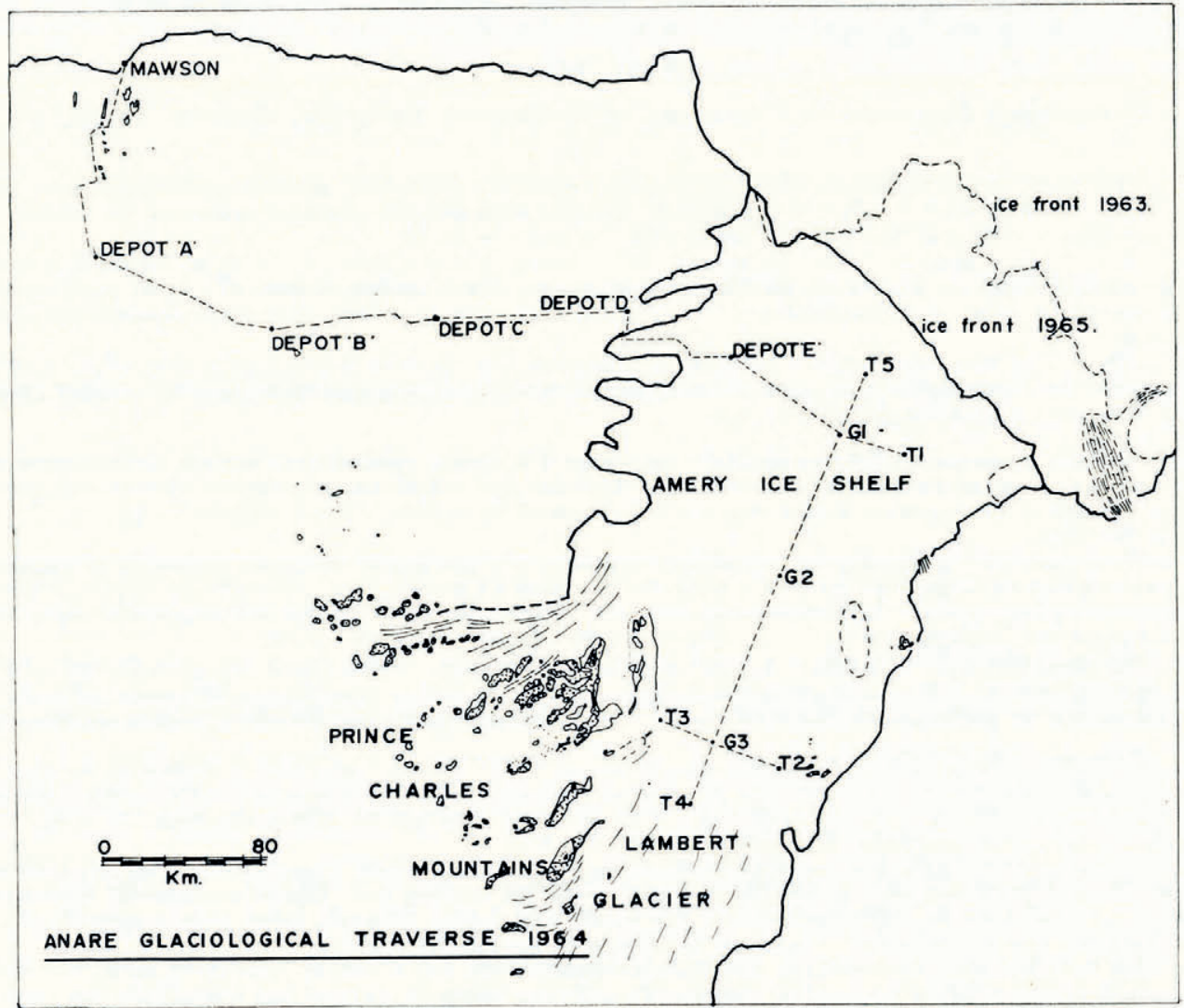

Fig. I. The route from Mawson to the Amery Ice Shelf and over the Amery Ice Shelf covered in 1963 and 1964. Accumulation stakes $3 \mathrm{~km}$. apart covered the ice-shelf route. Strain grids were located at E, G I, G2 and G3. Detailed sunfixes were carried out at E, G I, G2, G3 and $\mathrm{T} 2$

Table I. Measured Parameters on the Amery Ice Shelf

\begin{tabular}{|c|c|c|c|c|c|c|c|c|c|}
\hline \multirow{3}{*}{ Station } & \multicolumn{2}{|c|}{$\begin{array}{l}\text { Distance } \\
\text { from }\end{array}$} & \multirow[b]{2}{*}{$\begin{array}{c}\text { Elevation } \\
h\end{array}$} & \multicolumn{3}{|c|}{ Strain-rate: } & \multirow{2}{*}{\multicolumn{2}{|c|}{ Velocity Accumulation }} & \multirow{2}{*}{$\begin{array}{c}\text { Tempera } \\
\text { ture }\end{array}$} \\
\hline & $\begin{array}{l}\text { front } \\
x\end{array}$ & $\begin{array}{c}\text { Width } \\
2 a\end{array}$ & & $\begin{array}{c}\text { Slope } \\
\alpha\end{array}$ & $\begin{array}{c}\text { longitudinal } \\
\dot{\epsilon}_{x}\end{array}$ & $\begin{array}{c}\text { transverse } \\
\dot{\epsilon}_{y}\end{array}$ & & & \\
\hline & $\mathrm{km}$. & km. & $\mathrm{m}$. & $\times 10^{-4}$ & $\times \mathrm{IO}^{-3} \mathrm{yr}^{-1}$ & $\times \mathrm{IO}^{-3} \mathrm{yr}^{-1}$ & m. yr. ${ }^{-1} \mathrm{~g}$ & g. $\mathrm{cm} \cdot \cdot^{-2} \mathrm{yr}^{-1}$ & ${ }^{\circ} \mathrm{C}$. \\
\hline Edge & o & 200 & 35 & - & - & 一 & - & - & - \\
\hline & 34 & 180 & & - & - & - & - & 39 & $-19 \cdot 1$ \\
\hline I & 66 & 160 & $3^{8}$ & 0.4 & $6 \cdot 0$ & 0.8 & $800 \pm 100$ & 33 & $-20 \cdot 9$ \\
\hline $\mathrm{G} 2$ & 147 & 140 & $4^{2}$ & 0.6 & $1 \cdot 7$ & 0.05 & $500 \pm 25$ & $18 \cdot 2$ & $-22 \cdot 2$ \\
\hline G3 & 244 & 100 & $5^{2}$ & $1 \cdot 2$ & 0.5 & 0.15 & $4^{10} \pm 5^{\circ}$ & I0. 5 & -23.5 \\
\hline & 276 & 100 & & 2.8 & - & - & - & - & $\overline{ \pm 0} .0$ \\
\hline $\begin{array}{l}\text { Estimated } \\
\text { probable } \\
\text { error }\end{array}$ & \pm 2 & \pm 5 & $\begin{array}{l} \pm 2 \text { (edge) } \\
\pm 5\left(\mathrm{~T}_{4}\right)\end{array}$ & $\begin{array}{l} \pm \mathrm{O} \cdot \mathrm{I}(\mathrm{GI}) \\
\pm 0 \cdot 4(\mathrm{~T} 4)\end{array}$ & \pm 0.5 & $\pm 0 \cdot 5$ & - & \pm 2 & $\pm 0 \cdot 2$ \\
\hline
\end{tabular}

Glacier flows into the ice shelf. By comparison the flattest section of the Ross Ice Shelf (Crary and others, 1962, p. 26 ) is its central section which rises from 50 to $60 \mathrm{~m}$. in about $35^{\circ} \mathrm{km}$. giving a slope of $0.3 \times \mathrm{IO}^{-4}$. This slope increases as the boundary of the ice shelf is approached to values over $1.0 \times \mathrm{IO}^{-4}$. On the eastern side of the Ross Ice Shelf near "Little America" the slope is much greater, about $6 \times \mathrm{IO}^{-4}$ (Crary and Chapman, I963). 
Table II. Deduced Parameters for the Amery Ice Shelf

\begin{tabular}{|c|c|c|c|c|c|c|c|c|c|}
\hline \multirow[t]{3}{*}{ Station } & $\begin{array}{l}\text { Distance } \\
\text { from } \\
\text { front }\end{array}$ & Elevation & Thickness & Depth & $\begin{array}{c}\text { Elevation/ } \\
\text { thickness } \\
\text { ratio }\end{array}$ & $\begin{array}{c}\text { Mean } \\
\text { density }\end{array}$ & $\begin{array}{l}\text { Thinning } \\
\text { and } \\
\text { melt rate }\end{array}$ & $\begin{array}{l}\text { Density } \\
\text { relative to } \\
\text { sea-water }\end{array}$ & $\begin{array}{c}\text { Fractional } \\
\text { density } \\
\text { difference }\end{array}$ \\
\hline & $x$ & $h$ & H & $d$ & $H / h$ & $\bar{\rho}$ & $\partial H / \partial t+M$ & $\bar{\rho} / \rho_{\mathrm{w}}$ & $\nu=\mathrm{I}-\bar{\rho} / \rho$ \\
\hline & $\mathrm{km}$. & $\mathrm{m}$. & $\mathrm{m}$. & $\mathrm{m}$. & & g. $\mathrm{cm}^{-3}$ & $\mathrm{~cm} \cdot \mathrm{yr}^{-1}$ & & \\
\hline Edge & o & 35 & 200 & I 65 & $5 \cdot 71$ & 0.846 & - & $0 \cdot 824$ & о. I 76 \\
\hline T5 & $\begin{array}{l}34 \\
66\end{array}$ & 38 & $\overline{220}$ & $\overline{182}$ & $5 \cdot 78$ & 0.848 & - & $\overline{8}$ & - \\
\hline $\begin{array}{l}\mathrm{G} 1 \\
\mathrm{G} 2\end{array}$ & 147 & 42 & 245 & 203 & 5.85 & $\begin{array}{l}.040 \\
0.850\end{array}$ & $\begin{array}{r}-92 \\
-6\end{array}$ & $\begin{array}{l}0.827 \\
0.830\end{array}$ & $\begin{array}{l}0 \cdot 173 \\
0 \cdot 170\end{array}$ \\
\hline G3 & 244 & $5^{2}$ & 330 & 278 & $6 \cdot 3^{2}$ & 0.863 & 22 & 0.843 & 0.167 \\
\hline T4 & 276 & 74 & 530 & 456 & $7 \cdot 30$ & $0 \cdot 884$ & - & 0.863 & $0 \cdot 135$ \\
\hline
\end{tabular}

Since measurements of ice thickness along the Amery Ice Shelf have not yet been carried out, estimates of the ice thickness have been made from the ice thickness and elevation results for the Ross Ice Shelf of Crary and others (1962, p. 62). This is equivalent to postulating that the density distributions of the Ross and Amery Ice Shelves are similar. For a free-floating ice shelf the elevation $h$, thickness $H$, mean density $\bar{\rho}$, water density $\rho_{\mathrm{w}}$ are related by

$$
H=\left(\frac{\rho_{\mathrm{w}}}{\rho_{\mathrm{w}}-\bar{\rho}}\right) h .
$$

The resultant profile of the Amery Ice Shelf is shown in Figure 2 along with other associated parameters following the style of Zumberge and Swithinbank (1962) for the Ross Ice Shelf, but with the velocity, strain-rates and accumulation rates drawn to scale. This shows that the ice shelf increases slowly in thickness until it approaches the Lambert Glacier, where the thickness increases rapidly. The mean density through the ice shelf, calculated from the above thickness-elevation relation taking $\rho_{\mathrm{w}}=\mathrm{I} .025 \mathrm{~g} . \mathrm{cm} \cdot{ }^{-3}$, varies from $0.846 \mathrm{~g} . \mathrm{cm} \cdot .^{-3}$ at the front to $0.88 \mathrm{~g} . \mathrm{cm}^{-3}$ at the mouth of the Lambert Glacier.

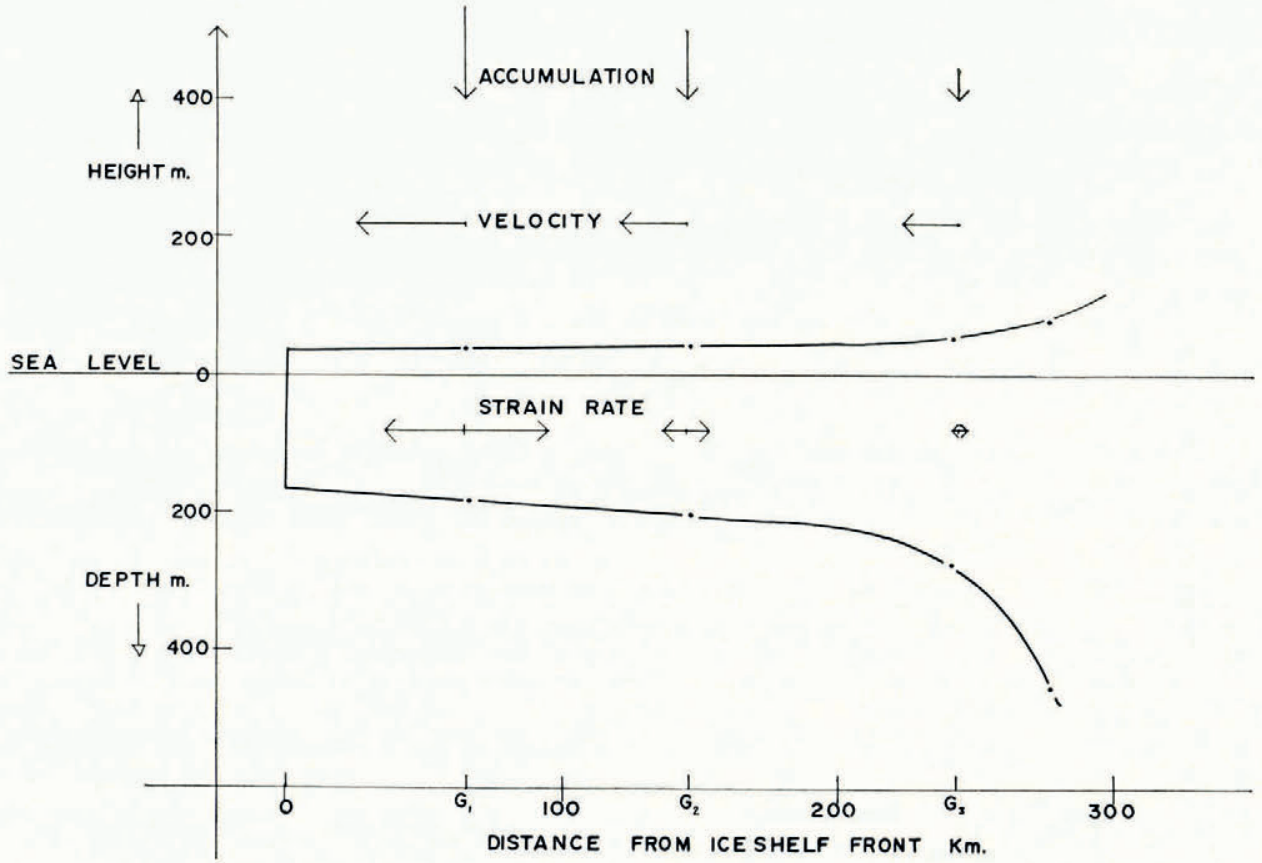

Fig. 2. Ice thickness profile for the Amery Ice Shelf estimated from the measured elevation profile from $\mathrm{T} 5$ to $\mathrm{T} 4$ and the elevationthickness results of Crary for the Ross Ice Shelf. Velocity, longitudinal strain-rate, and accumulation rate along the ice shelf are shown schematically to scale 
The central section of the ice shelf traversed in 1964 was smooth and featureless, except for some long tension crevasses in the vicinity of $\mathrm{T}_{5}$, at the northern end, running parallel to the new ice front, and for slight transverse undulations at the southern end near the mouth of the Lambert Glacier where the slope increases from $\mathrm{G}_{3}$ to $\mathrm{T} 4$.

\subsection{Velocity}

Measurements of velocity for positions E, GI, G2, G3 were obtained from astronomical fixes repeated after one year with probable errors of $\pm 100 \mathrm{~m}$. However the measured values agreed well with the values calculated from the measured strain-rates, so values calculated to the nearest $10 \mathrm{~m} . \mathrm{yr}^{-1}$ are listed in Table I and are shown in Figure 3. In addition the velocity value at G2 was confirmed by a repeated resection to rock features of Gillock Island. A similar resection to the northern Prince Charles Mountains carried out at $\mathrm{G}_{3}$ established an upper limit on its velocity.

The ice-shelf speed (cf. Fig. 3) shows a rapid increase towards the ice front. This is further confirmed by the value of the velocity found at the former ice front in 1963 of $\mathrm{I}, 500 \mathrm{~m} . \mathrm{yr} .^{-1}$ (Landon-Smith [1964]). If the creep rate were constant along the ice shelf then a linear increase of velocity towards the front would be expected.

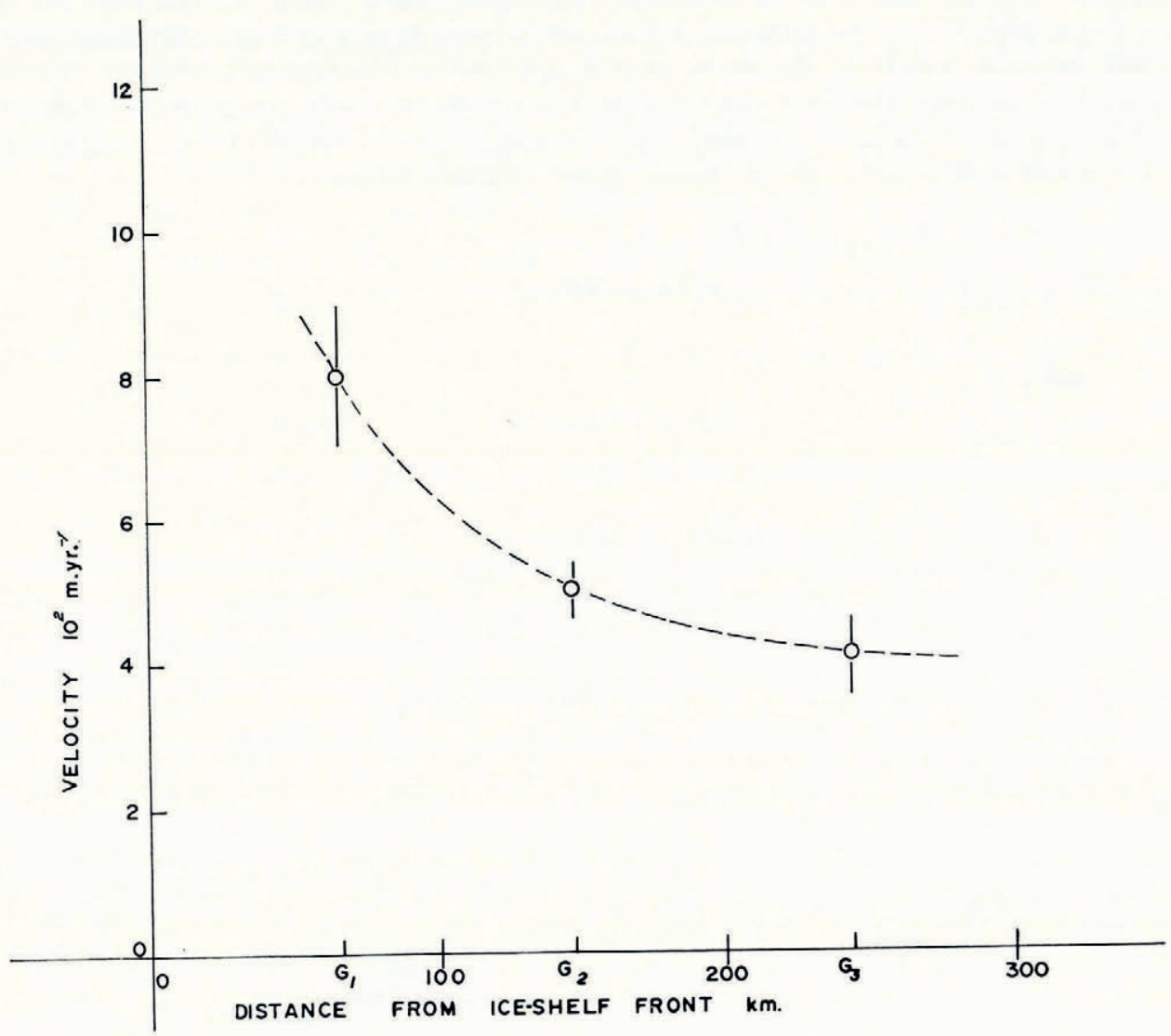

Fig. 3. Velocity distribution along the Amery Ice Shelf centre-line is shown, as determined from repeated astrofixes at $\mathrm{G} 1, \mathrm{G} 2, \mathrm{G} 3$ and resections to rock features at $\mathrm{G} 2$ and $\mathrm{G} 3$ 


\subsection{Strain-rates}

Not only does the velocity increase rapidly towards the front but so also does the creep rate. The measured longitudinal strain-rate is plotted against the distance inland from the ice front $(x)$ in Figure 4, and shows a tendency to decrease to zero as $x$ increases. On the other hand the velocity curve does not tend to zero, but appears to approach asymptotically a value of about $370 \mathrm{~m}$. yr. $^{-1}$. This velocity is expected to be the surface velocity of the ice at the mouth of the Lambert Glacier.

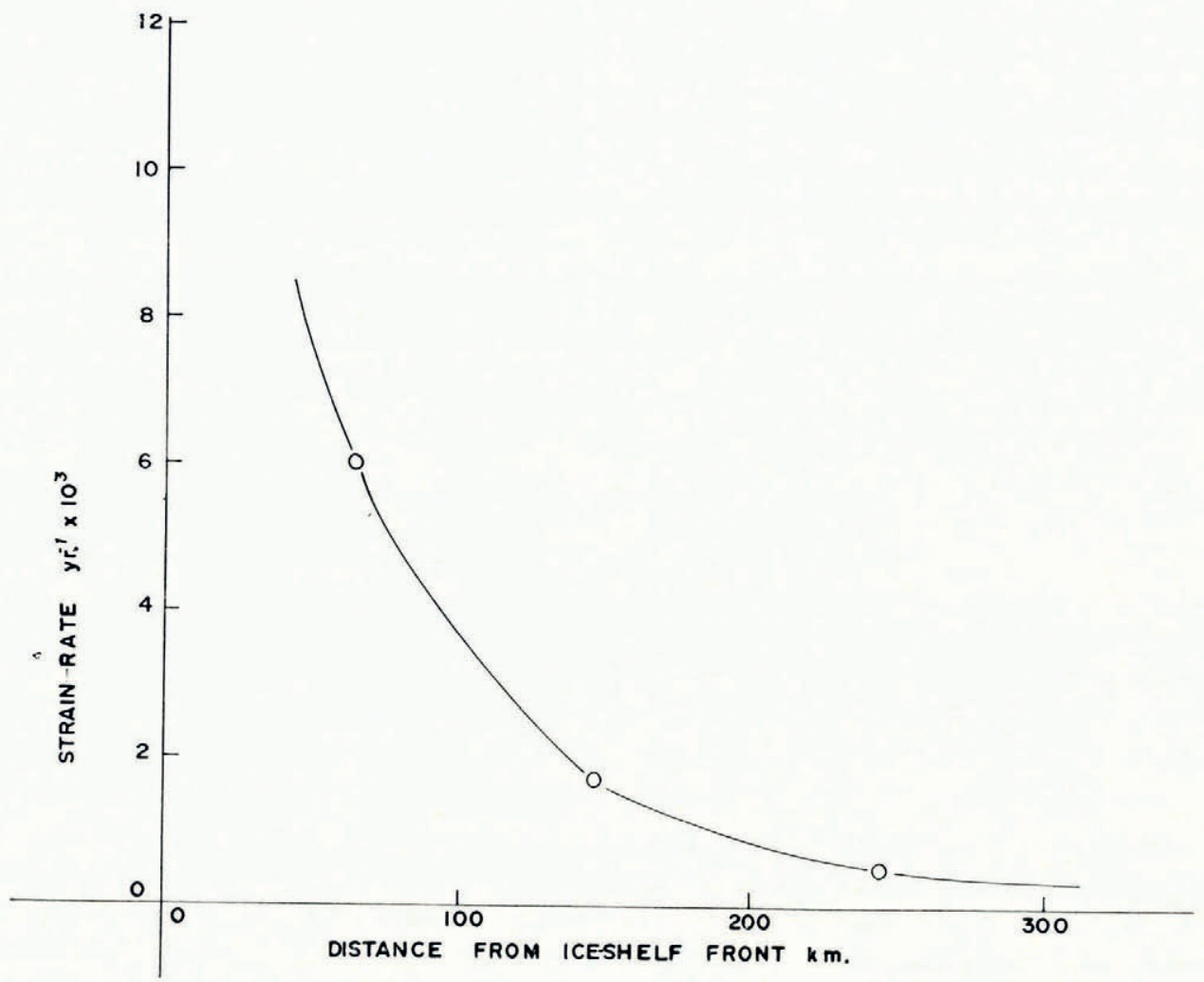
Fig. 4. Longitudinal strain-rate along the ice shelf as determined from measurements of strain grids with diagonals of $1,500 \mathrm{~m}$.
re-surveyed after one year, at $\mathrm{G} \mathrm{I}, \mathrm{G} 2$ and $\mathrm{G} 3$

The transverse strain rate of an ice shelf has been discussed by Robin (1958, p. I2I) who showed how the transverse strain-rate is simply related to the forward velocity and the divergence of the flow lines. That this is quite general can be seen as follows. Consider an ice shelf flowing outwards with diverging flow lines. Let $\theta$ be the angle of divergence of two flow lines which are distance $d$ apart at a certain position. Let $u$ and $v$ be the forward and transverse components of velocity of the ice shelf. We now take polar coordinates $(r, \theta)$ where $r$ is given by $d=r \theta$. The radial strain-rate (the rate of extension per unit length of a line in the direction of flow, $\dot{\epsilon}_{r}$ ) and the transverse strain rate (the rate of extension of a line perpendicular to the direction of flow, $\dot{\epsilon}_{\theta}$ ) are given by

(cf. e.g. Jaeger, I956, p. 45).

$$
\dot{\epsilon}_{r}=\frac{\partial u}{\partial r} \quad \text { and } \quad \dot{\epsilon}_{\theta}=\frac{\mathrm{I}}{r}\left(u+\frac{\partial v}{\partial \theta}\right)
$$


Now $v$ is small where the flow lines have a small divergence angle and $\partial v / \partial \theta$ is negligible over the ice shelf in comparison with $u$. Hence we write

$$
\dot{\epsilon}_{\theta}=\frac{u \theta}{d} \quad \text { or } \quad \theta=\frac{d \dot{\epsilon}_{\theta}}{u} \text {. }
$$

By smoothing the boundaries of the Amery Ice Shelf we can measure the average divergence angles of the boundary, then from the measured transverse strain-rates at GI, G2, G3 calculate the appropriate velocities to compare with the measured values. Alternatively we could use the velocities to calculate transverse strain-rates. These calculations have been performed but give velocities too low or strain-rates too high. From this we conclude that the divergence angles are smaller than the smoothed boundary divergence. Hence we calculate from the measured velocities and strain-rates the appropriate divergence angles. Table III shows the calculated angles of divergence for the Amery Ice Shelf at G I, G2 and G3.

\section{Table III. Calculation of Divergence of Flow Lines}

$\begin{array}{ccccc}\text { Position } & \begin{array}{c}\text { Transverse } \\ \text { strain-rate }\end{array} & \text { Velocity } & \begin{array}{c}\text { Ice-shelf } \\ \text { width }\end{array} & \begin{array}{c}\text { Divergence } \\ \text { angle }\end{array} \\ \dot{\epsilon}_{\theta} & u & d & \bar{\theta}=\frac{d \dot{\epsilon}_{\theta}}{u} \\ \text { GI } & 0.8 \times \mathrm{IO}^{-3} & 0.80 & 160 & 0.16=9^{\circ} \\ \text { G2 } & 0.05 \times 10^{-3} & 0.50 & 140 & 0.014=0.7^{\circ} \\ \text { G3 } & 0.15 \times 10^{-3} & 0.41 & 110 & 0.04=2.3^{\circ}\end{array}$

These angles are somewhat smaller than the angles of divergence of the ice-shelf boundary, but because of the irregularities in the boundary these latter angles are difficult to determine precisely. The presence of Gillock Island in the region of G2 may also account for the small transverse strain-rate there.

\subsection{Accumulation}

Figures 5 and 6 show the annual net accumulation over the ice shelf by a longitudinal profile down the centre and the transverse profiles at each end. The accumulation rate decreases fairly uniformly from $40 \mathrm{~g} . \mathrm{cm}$. $\mathrm{yr}^{-1}$ near the ice front to zero on the Lambert Glacier, where a blue ice surface prevails.

There is only slight variation in accumulation rate across the ice shelf at either end. The small sastrugi, which are oriented predominantly along a direction $200^{\circ}$ from true north at the west side and $160^{\circ}$ at the east side, suggest that winds over the area (which are slight) blow mainly longitudinally down the ice shelf.

The longitudinal profile (Fig. 5) shows the variation in accumulation with distance from the 1965 ice front as measured from stakes during 1964 , and from the pit studies of LandonSmith in 1962. The two profiles are similar except near the front of the ice shelf, but this dissimilarity is accounted for by the change in position of the front by about $60 \mathrm{~km}$. The values of the 1964 accumulation are slightly higher than those found by Crary (ig6i, p. 75) for the Ross Ice Shelf, "Little America"- "Byrd" line, and considerably higher than those found over the main central section of the Ross Ice Shelf by Crary and others (ig62, p. 93). For the Amery Ice Shelf Landon-Smith found an average variation of II per cent in accumulation rate from one year to another.

The average density of the surface annual layer was found to be $0.35 \mathrm{~g} . \mathrm{cm}^{-3}$. This increased to an average $0.49 \mathrm{~g} . \mathrm{cm} \cdot{ }^{-3}$ at $6 \mathrm{~m}$. depth. 


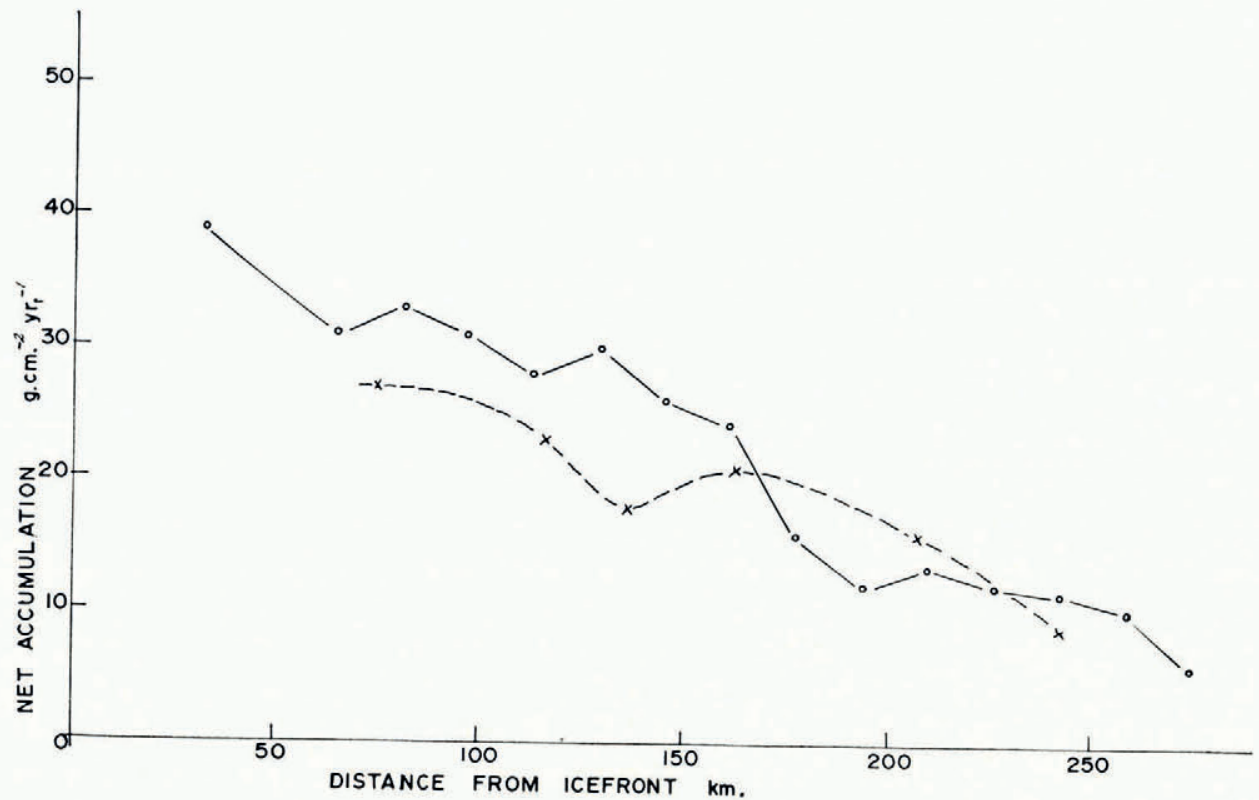

Fig. 5. Accumulation rate along the ice shelf from $\mathrm{T}_{5}$ to $\mathrm{T} 4$ as obtained from the mean of 5 stakes each $16 \mathrm{~km}$. planted in 1963 and re-read in $1964(0)$, and from the mean over several years from the pit studies of Landon-Smith in $1962(\times)$. Note that since 1963 the ice front is about $60 \mathrm{~km}$. closer than previously. The values of accumulation have been converted from the equivalent snow depth by using a constant density factor of $0.35 \mathrm{~g} . \mathrm{cm} .^{-3}$

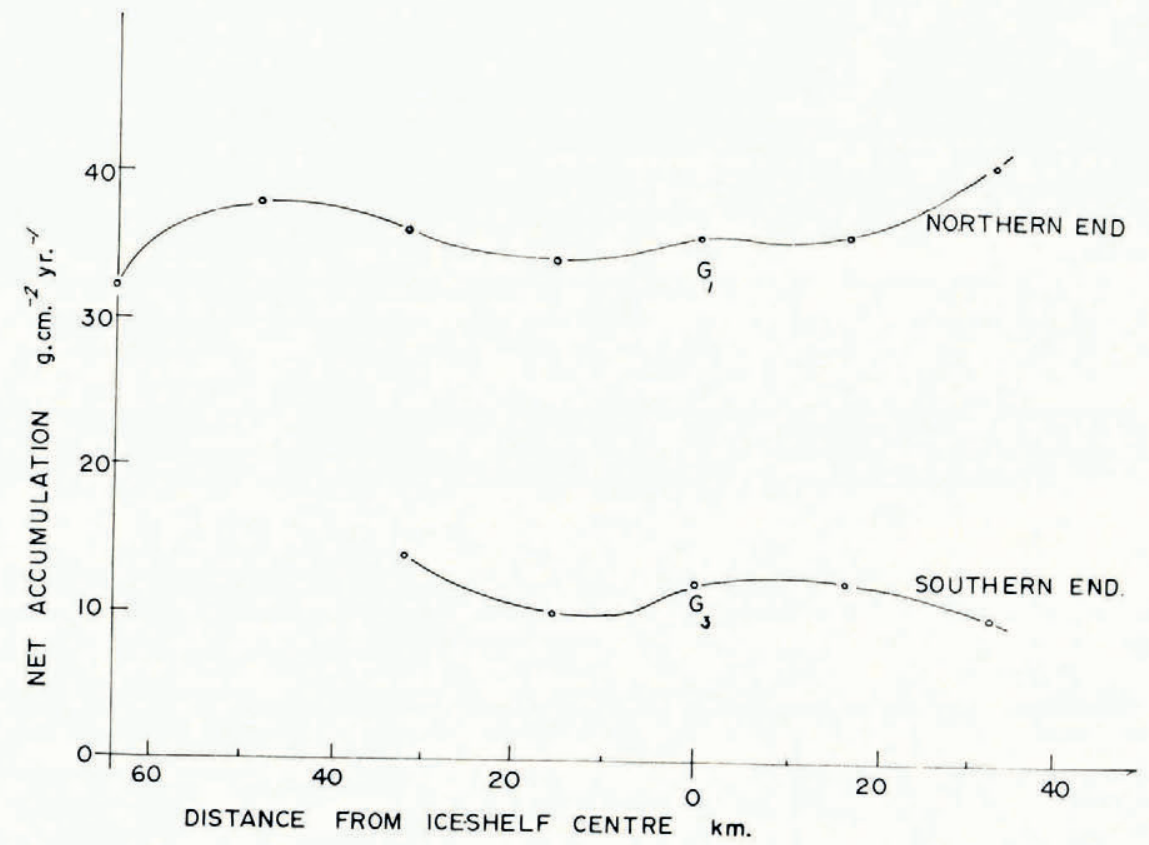

Fig. 6. Variation in accumulation rate across the ice shelf as shown from the average accumulation measurements of the stake lines $\mathrm{E}, \mathrm{GI}, \mathrm{TI} ; \mathrm{T} 3, \mathrm{G} 3, \mathrm{~T} 2$. There is little variation across the ice shelf compared with along the ice shelf 
Figure 7 shows the accumulation-rate contours over the ice shelf. The average annual net accumulation for the whole ice shelf was calculated as $28 \mathrm{~g} . \mathrm{cm} \cdot{ }^{-2}$.

\subsection{Temperature}

Annual mean temperatures for the ice-shelf surface have been estimated from the temperature profiles measured in the top ro $\mathrm{m}$. of the surface. The measurements were carried out in 1962,1963 and 1964 . Figure 8 shows the decrease in annual mean temperature along the ice-shelf centre as the distance from the front increases. Near the ice front, as the ocean is approached, the rate of change of temperature is high, whereas further inland it is much smaller. The annual mean temperature at the ice front is expected to be not far below Mawson's annual mean temperature of $-\mathrm{II}^{\circ} \mathrm{C}$.

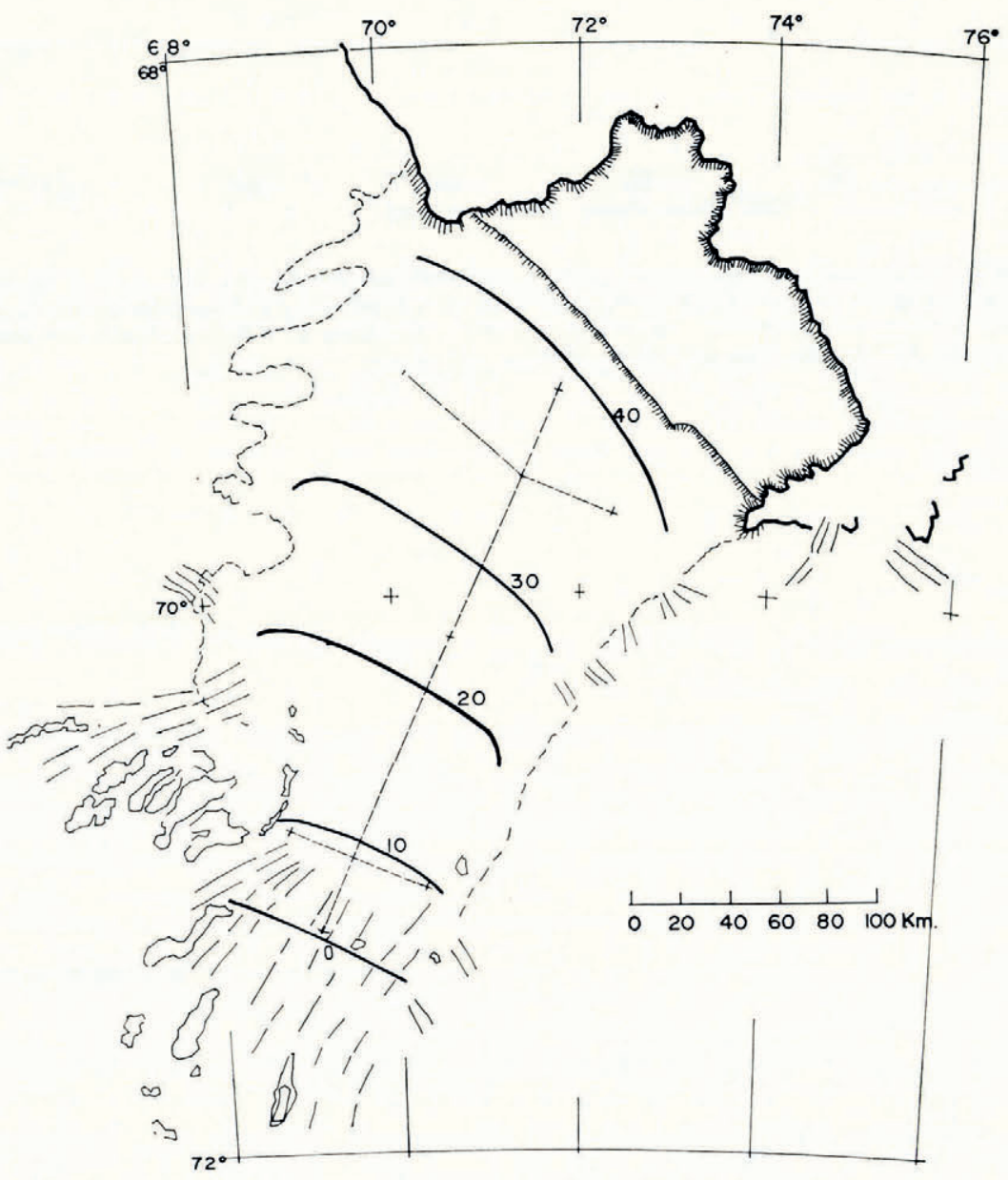

Fig. 7. Annual net accumulation contours in $\mathrm{g} . \mathrm{cm} .^{-2} y r .^{-1}$ over the Amery Ice Shelf drawn from the longitudinal and transverses profile of Figures 5 and 6 . The higher accumulation at the edges is decided largely from the high accumulation found between $\mathrm{E}$ and $\mathrm{D}$ 


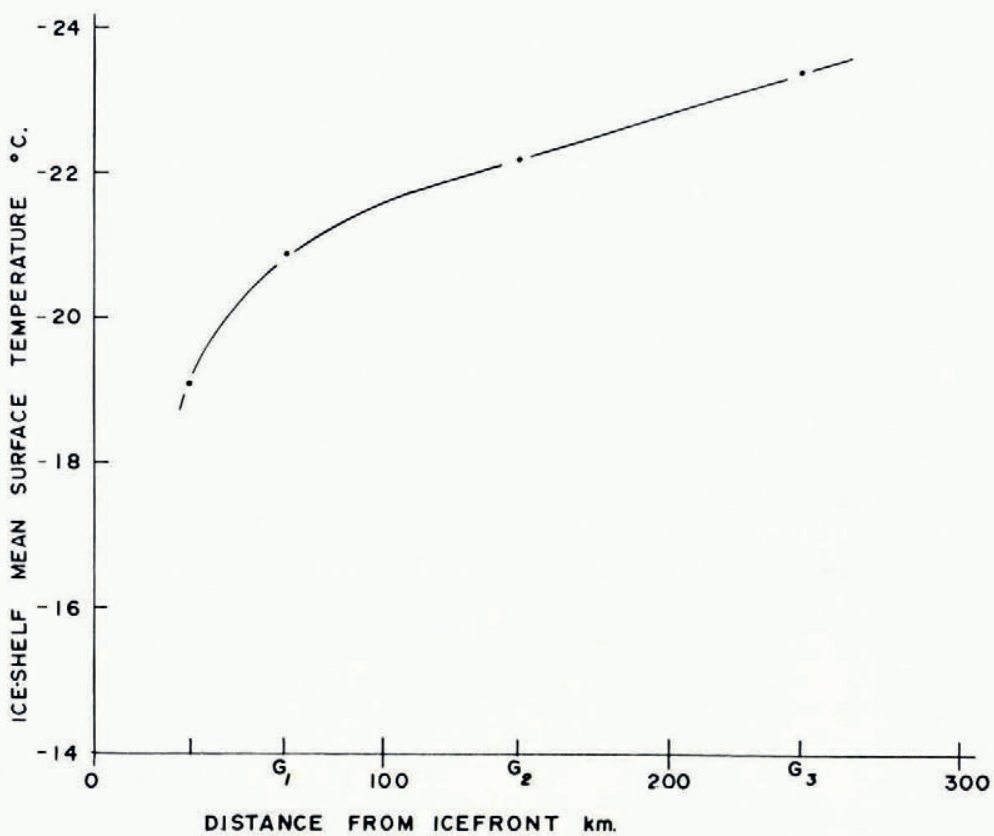

Fig. 8. The annual mean air temperature on the surface of the Amery Ice Shelf plotted against the distance from the front. The values were determined from the temperalures in the firn between 4 and $10 \mathrm{~m}$. from $\mathrm{T}_{5}$ to $\mathrm{G} 3$

\section{Theory of Ice-shelf Velocity Profiles}

\section{I. Longitudinal velocity profile}

3.I.I. The Weertman formula

The creep rate of a flat, horizontal, unbounded ice shelf has been considered by Weertman (1957). Take orthogonal axes with $x$ in the line of motion, $z$ vertical from the bottom upwards, and $y$ across the ice shelf. We use the following notation

$\sigma_{i j}$ the stress tensor at $(x, y, z)$, i.e. at $x_{i}$, where $i=\mathrm{I}, 2,3$

$\dot{\epsilon}_{i j} \quad$ the strain-rate tensor at $(x, y, z), \dot{\epsilon}_{i j}=\frac{\mathrm{I}}{2}\left[\frac{\partial u_{j}}{\partial x_{i}}+\frac{\partial u_{i}}{\partial x_{j}}\right]$

$u_{i} \quad$ velocity vector at $x_{i}$

$H$ ice-shelf thickness

$\rho_{\text {i }} \quad$ average ice-shelf density

$\rho_{\mathrm{w}} \quad$ sea-water density

$K$ average horizontal longitudinal creep rate, assumed uniform through the ice shelf

$B, n$ parameters of the power law for ice flow $\dot{\epsilon}=(\tau / B)^{n}$ where $\dot{\epsilon}$ is the effective shear strain-rate and $\tau$ is the effective shear stress.

The equations for equilibrium are

$$
\begin{gathered}
\frac{\partial \sigma_{x x}}{\partial x}+\frac{\partial \sigma_{x y}}{\partial y}+\frac{\partial \sigma_{x y}}{\partial z}=0 \\
\frac{\partial \sigma_{y y}}{\partial y}+\frac{\partial \sigma_{x y}}{\partial x}+\frac{\partial \sigma_{y z}}{\partial z}=0 \\
\frac{\partial \sigma_{z z}}{\partial z}+\frac{\partial \sigma_{x z}}{\partial x}+\frac{\partial \sigma_{y z}}{\partial y}+\rho_{\mathrm{i}} g=0
\end{gathered}
$$


Weertman then made the assumptions:

(i) (a) the stress components are independent of $x$ (the stress gradient down the ice shelf is negligible, compared with the vertical gradient), and

(b) the stress components are independent of $y$ (the stress gradient across the ice shelf is negligible).

The equations of equilibrium then reduce to

and

$$
\begin{gathered}
\frac{\partial \sigma_{z z}}{\partial z}+\rho_{\mathrm{i}} g=0 \\
\sigma_{x y}=\sigma_{x z}=\sigma_{y z}=0 .
\end{gathered}
$$

Adopting Nye's relation for steady-state creep, Weertman deduced for the case of zero transverse creep the following relation for the horizontal stress at depth $z$ :

$$
\sigma_{x x}= \pm 2 B|K|^{\mathrm{I} / n}-\rho_{\mathrm{i}} g(H-z) .
$$

By making the further assumption:

(ii) at the front of the ice shelf the horizontal force in the ice is balanced by that in the water, i.e.

$$
\int_{0}^{H} \sigma_{x x} d z=\frac{1}{2} \rho_{\mathrm{i}} g H^{2} \rho_{\mathrm{i}} / \rho_{\mathrm{w}},
$$

Weertman obtained for the creep rate

$$
K=\left[\frac{v \rho_{\mathrm{i}} g H}{{ }_{4} \bar{B}}\right]^{n}
$$

where

$$
v=\left(\mathrm{I}-\rho_{\mathrm{i}} / \rho_{\mathrm{w}}\right) \text { and } \bar{B}=\frac{\mathrm{I}}{H} \int_{\mathrm{o}}^{H} B d z .
$$

Now if equation (3) were to hold along the Amery Ice Shelf we find that the creep rate would have to increase, going from G I to G3, due mainly to the increase in $H$ (by about $5^{\circ}$ per cent). In fact $K$ decreases by a factor of 12 . The change in $\bar{B}$ can be estimated from the change in surface temperature from G I to $\mathrm{G} 3$ - a decrease of $2.6^{\circ} \mathrm{C}$.

Assuming the form of the temperature-depth distribution does not change radically along the ice shelf then the change in mean temperature is about $2^{\circ} \mathrm{C}$. From Figure i I we can see the temperature change in $B$ around $-20^{\circ} \mathrm{C}$ is not far from linear. Hence from GI to G3 we may expect a change in $\bar{B}$ of about I 5 per cent. From Table II it can be seen that $\bar{\rho}$ only increases slightly and $v$ decreases slightly. We have

whereas

$$
\begin{gathered}
\frac{v_{3} \rho_{3} H_{3} B_{\mathrm{I}}}{v_{\mathrm{I}} \rho_{\mathrm{I}} H_{\mathrm{I}} B_{3}} \cong \mathrm{I} \cdot 3 \\
\frac{K_{3}}{K_{\mathrm{I}}}=\frac{\mathrm{I}}{\mathrm{I} 2} .
\end{gathered}
$$

So in order to explain the observed variation in velocity and velocity gradient along the ice shelf we consider the effect of the ice shelf being held at its sides.

3.1.2. Velocity gradient in an ice shelf with lateral constraint

For a flat ice shelf of width $2 a$, deforming according to a power flow law of the form $\dot{\epsilon}=(\tau \mid B)^{n}$, and held at its sides where the velocity is zero, the velocity at the centre (for purely laminar flow) is given by

$$
V=\frac{2 a^{n+1}}{(n+\mathrm{I}) B^{n}}\left[\frac{d^{\prime} p}{d^{\prime} x}\right]^{n}
$$


where $d p / d x$ is the uniform pressure gradient down the ice shelf (cf. Nye, I952, p. 84; Jaeger, I956, p. го9).

This result can be deduced from the general equations of equilibrium by assuming:

(iii) the velocity gradients other than $\partial V / \partial y$ (across the ice shelf) are sufficiently small to be neglected.

Now equation (4) shows that the effect of the drag of the sides on the ice shelf is to balance a pressure gradient down the ice shelf. For the Amery Ice Shelf it appears that this drag of the sides should be used to balance the stress gradient in the ice shelf rather than the force of the water of Weertman's assumption (ii).

Along the centre-line of the ice shelf Weertman's assumptions (i) hold closely. It can be seen, in section 3.5 , that the pressure gradient down the ice shelf, $\partial \sigma_{x x} / \partial x$, is several orders smaller than the stress gradient with depth, $\partial \sigma_{z z} / \partial z$, and hence assumption (i) (a) holds. Due to symmetry, assumption (i) (b) holds along the centre-line of the ice shelf. Hence Weertman's equation ( $\mathrm{I}$ ) holds here.

Averaging equation (I) vertically through the ice shelf we obtain

$$
\bar{\sigma}_{x x}={ }_{2} \bar{B} K^{\mathrm{I} / n}-\frac{1}{2} \bar{\rho} g H .
$$

Now, considering $B$ and $\rho$ to be constant along the ice shelf, we may differentiate this equation with respect to $x$ to obtain (dropping the bars)

$$
\frac{\partial \sigma_{x x}}{\partial x}={ }_{2} B \frac{\partial K^{\mathrm{I} / n}}{\partial x}+\frac{\mathrm{I}}{2} \rho g \frac{\partial H}{\partial x} .
$$

On the other hand if equation (4) holds we have

$$
\frac{d p}{d x}=B\left[\frac{(n+\mathrm{I}) V}{2 a^{n+\mathrm{x}}}\right]^{\mathrm{I} / n} .
$$

Now equation (4) will hold approximately if the velocity gradient from the centre to the edge $\partial V / \partial y$ is much greater than the other velocity gradients, in particular $\partial V / \partial x$. Now except near the centre this is indeed so-and since the velocity at the centre is determined primarily by higher shear away from the centre of the ice shelf, equation (4) should hold until the longitudinal creep rate becomes so large as to be comparable with the velocity gradient across the ice shelf.

Hence for the first approximation we make the assumption:

(iv) the longitudinal pressure gradient is constant across the ice shelf, i.e. the longitudinal velocity gradient is small compared to the transverse gradient so that equation (4) holds,

i.e. we assume

$$
\frac{d p}{d x}=\frac{\partial \sigma_{x x}}{\partial x}
$$

which then gives

$$
B\left[\frac{(n+\mathrm{I}) V}{2 a^{n+\mathrm{I}}}\right]^{\mathrm{I} / n}=2 B \frac{d K^{\mathrm{I} / n}}{d x}+\frac{\mathrm{I}}{2} \rho g \frac{d H}{d x} .
$$

This equation relates the velocity $V$ and velocity gradient $K$ to the boundary dimensions of the ice shelf $H, a, x$, and the flow parameters $n, B$, of the ice shelf.

We notice that, unlike the unconstrained ice-shelf model of Weertman, the creep rate here could be positive or negative depending on the relative size of the terms in $V$ and $d H / d x$, and the distance from the front. This follows from the integration of equation (7) with respect to $x$.

The problem now is to determine from the measured velocity distribution and boundary dimensions of the Amery Ice Shelf the most appropriate values of $n$ and $B$. We first consider three special cases. 
For an ice-shelf region where the slope is large and the creep rate small (as at the southern end of the Amery Ice Shelf) it is expected that the second term on the right of equation (7) would predominate giving us

$$
V=\left[\frac{\rho g d H}{2 B d x}\right]^{n} \frac{2 a^{n+\mathrm{r}}}{n+\mathrm{I}} .
$$

On the other hand for a flat ice shelf where the creep rate is high (as towards the front of the Amery Ice Shelf) we obtain

i.e. $\quad \frac{d^{2} V}{d x^{2}}=\mu\left[\frac{d V}{d x}\right]^{\mathrm{I}-\mathrm{I} / n} V^{\mathrm{I} / n}$

$$
\left[\frac{n+\mathrm{I}}{2 a^{n+1}}\right]^{\mathrm{I} / n} V^{\mathrm{I} / n}=\frac{2 B}{n}\left[\frac{d V}{d x}\right]^{(\mathrm{I} / n)-\mathrm{I}} \frac{d^{2} V}{d x^{2}},
$$

where

$$
\mu=\frac{n(n+\mathrm{I})^{\mathrm{I} / n}}{(2 a)^{(n+\mathrm{I}) / n}} \text {. }
$$

Finally for the particular case $n=\mathrm{I}$ we obtain

or

$$
\begin{gathered}
\frac{B V}{a^{2}}=2 B \frac{d K}{d x}-\frac{\rho g}{2} \frac{d H}{d x}, \\
\frac{d^{2} V}{d x^{2}}-\frac{V}{2 a^{2}}=\frac{\rho g}{4 B} \frac{d H}{d x} .
\end{gathered}
$$

We can see from equation (8) above that since $d H / d x$ decreases towards the front of the ice shelf, and $a$ only increases slightly, this equation could not explain the rapid increase observed in the velocity gradient.

Next we consider the effect of the varying creep rate along the ice shelf. Solutions of equation (9) exist in the form

$$
\left.\begin{array}{rl}
V & =V_{\mathrm{o}} \exp (-\lambda x), \\
\frac{d V}{d x} & =-\lambda V_{\mathrm{o}} \exp (-\lambda x)=-\lambda V,
\end{array}\right\}
$$

where $\lambda=\mu^{n /(n+\mathrm{I})}$ and $V_{\mathrm{o}}$ is the velocity at the front of the ice shelf, where $x=\mathrm{o}$ say, with $x$ increasing inland from the front. This solution implies that both the velocity and the velocity gradient (at the centre of the ice shelf) decrease exponentially going inland from the ice front - the rate of decrease depending on the parameter $n$ of the flow law and the ice-shelf width. However, this solution also implies $V \rightarrow 0$ as $d V / d x \rightarrow 0$, and may well apply to some flat ice shelves. For the Amery Ice Shelf, on the other hand, as $d V / d x \rightarrow 0$ the velocity approaches the value $V_{\mathrm{I}} \approx 370 \mathrm{~m}$. yr. ${ }^{-\mathrm{I}}$, and at the same time the surface slope increases by a factor of about four. This suggests that near the back of the ice shelf the pressure gradient due to the surface slope becomes the dominant factor.

For the case of constant viscosity $(n=\mathrm{I})$ we see that the various pressure gradients are simply superimposable and may be considered independently. The appropriate solution of equation (II) is

$$
V=V_{\mathrm{o}} \exp (-\lambda x)+\frac{\rho g a^{2}}{2 B} \frac{d H}{d x}
$$

Since none of the special solutions are directly applicable to the Amery Ice Shelf the following approximate solution of the general equation (7) will be applied.

Let the pressure gradient due to the thickness gradient be $d p_{\mathrm{I}} / d x$ and let $V_{\mathrm{I}}$ be the velocity 
it would give rise to alone for equilibrium. Let $V_{\mathrm{C}}$ be the velocity due to the effect of the change in creep rate, so that the total velocity is $V=V_{\mathrm{I}}+V_{\mathrm{C}}$. We now have

$$
\begin{aligned}
{ }_{2} B \frac{d K^{\mathrm{I} / n}}{d x} & \propto \frac{d p}{d x}-\frac{d p_{\mathrm{I}}}{d x} \\
& \propto\left(V_{\mathrm{I}}+V_{\mathrm{C}}\right)^{\mathrm{I} / n}-V_{\mathrm{I}^{\mathrm{I} / n}} .
\end{aligned}
$$

If we write $V_{\mathrm{C}}=\beta V_{\mathrm{I}}$, we have

$$
2 B \frac{d K^{\mathrm{I} / n}}{d x} \propto V_{\mathrm{C}^{\mathrm{I}} / n}\left[\frac{(\beta+\mathrm{I})^{\mathrm{I} / n}-\mathrm{I}}{\beta^{\mathrm{I} / n}}\right] .
$$

Equation (9) now becomes

$$
\frac{d^{2} V}{d x^{2}}=\mu^{\prime}\left[\frac{d V}{d x}\right]^{1-1 / n} V^{1 / n}
$$

where

$$
\mu^{\prime}=\mu\left[\frac{(\beta+\mathrm{I})^{\mathrm{I} / n}-\mathrm{I}}{\beta^{\mathrm{I} / n}}\right] \text {. }
$$

Solutions then exist for $V_{\mathrm{C}}$ of the form (I2) with $\lambda^{\prime}=\left(\mu^{\prime}\right)^{n /(n+1)}$ provided $\lambda^{\prime}$ does not vary significantly with $x$. Values of $\left[\frac{(\beta+\mathrm{I})^{\mathrm{I} / n}-\mathrm{I}}{\beta^{\mathrm{I} / n}}\right]^{n /(n+\mathrm{I})}=b_{n}(\beta)$ say, have been plotted against $\beta$ for various values of $n$ in Figure 9. Except where $\beta$ is small, $b_{n}(\beta)$ varies slowly with $\beta$ and hence we may expect the approximation to be close towards the front of the ice shelf.

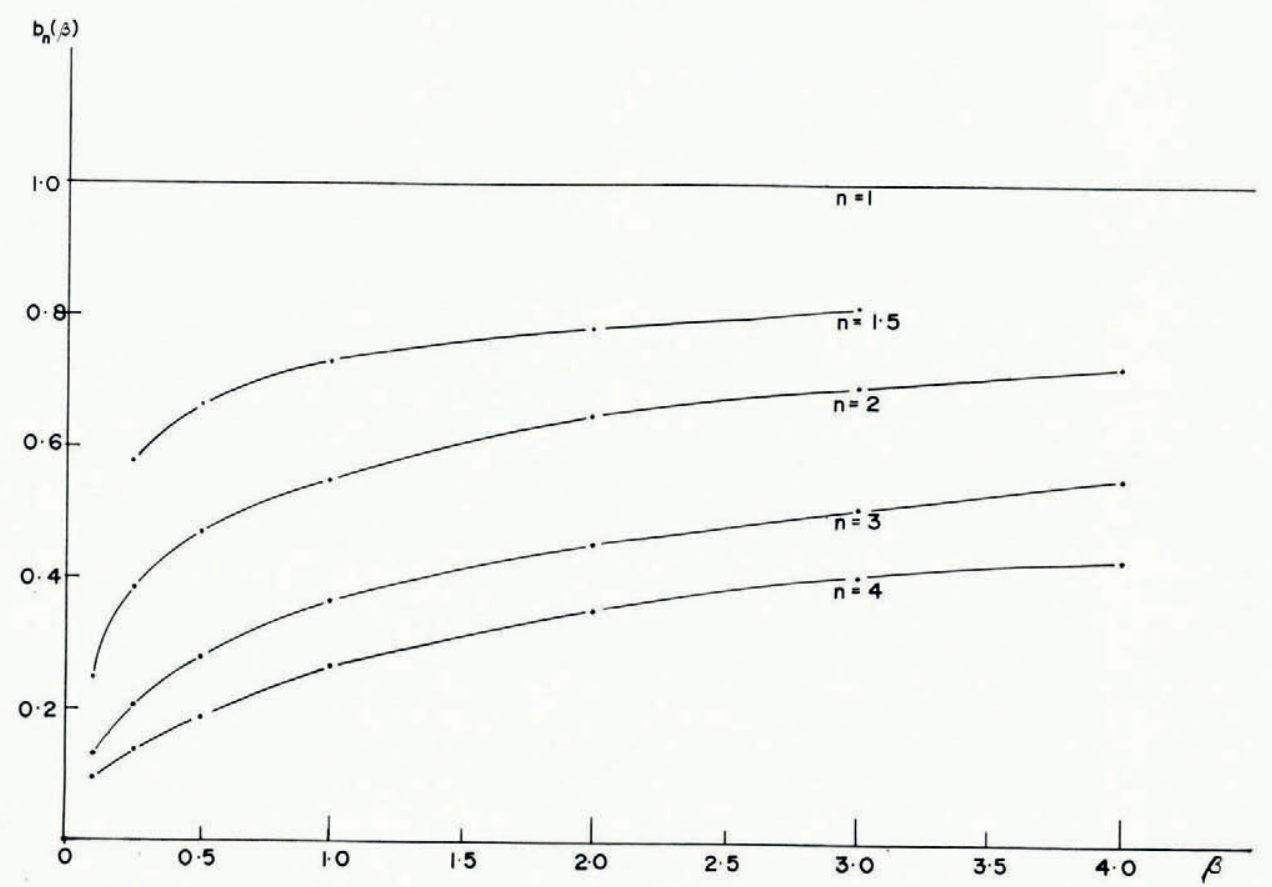

Fig. 9. The function $b_{n}(\beta)$ plotted against $\beta$ for different values of $n$. $\beta$ is the ratio of the velocity due to creep gradient to that due to thickness gradient. For large $\beta, b_{n}(\beta)$ is only a slowly changing. function, and more slowly the lower the value of $n$ 


\subsection{Value of parameter $n$}

We write the solution of equation $\left(9^{\prime}\right)$ in the form

where

$$
\begin{gathered}
V=V_{\mathrm{I}}+V_{\mathrm{C}} \\
=V_{\mathrm{I}}+V_{\mathrm{o}} \exp [-\phi(n) x / a] \\
\phi(n)=\frac{n(n+\mathrm{I})^{\mathrm{I} / n}}{2^{(n+\mathrm{I}) / n}}\left[\frac{(\beta+\mathrm{I})^{\mathrm{I} / n}-\mathrm{I}}{\beta^{\mathrm{I} / n}}\right]^{n /(n+\mathrm{I})}
\end{gathered}
$$

and $\left(V_{\mathrm{I}}+V_{\mathrm{o}}\right)$ is the velocity at the ice front, where $x=0, x$ increasing inland. The function $\phi(n)$ has been plotted in Figure ro for different values of $n$ and $\beta$.

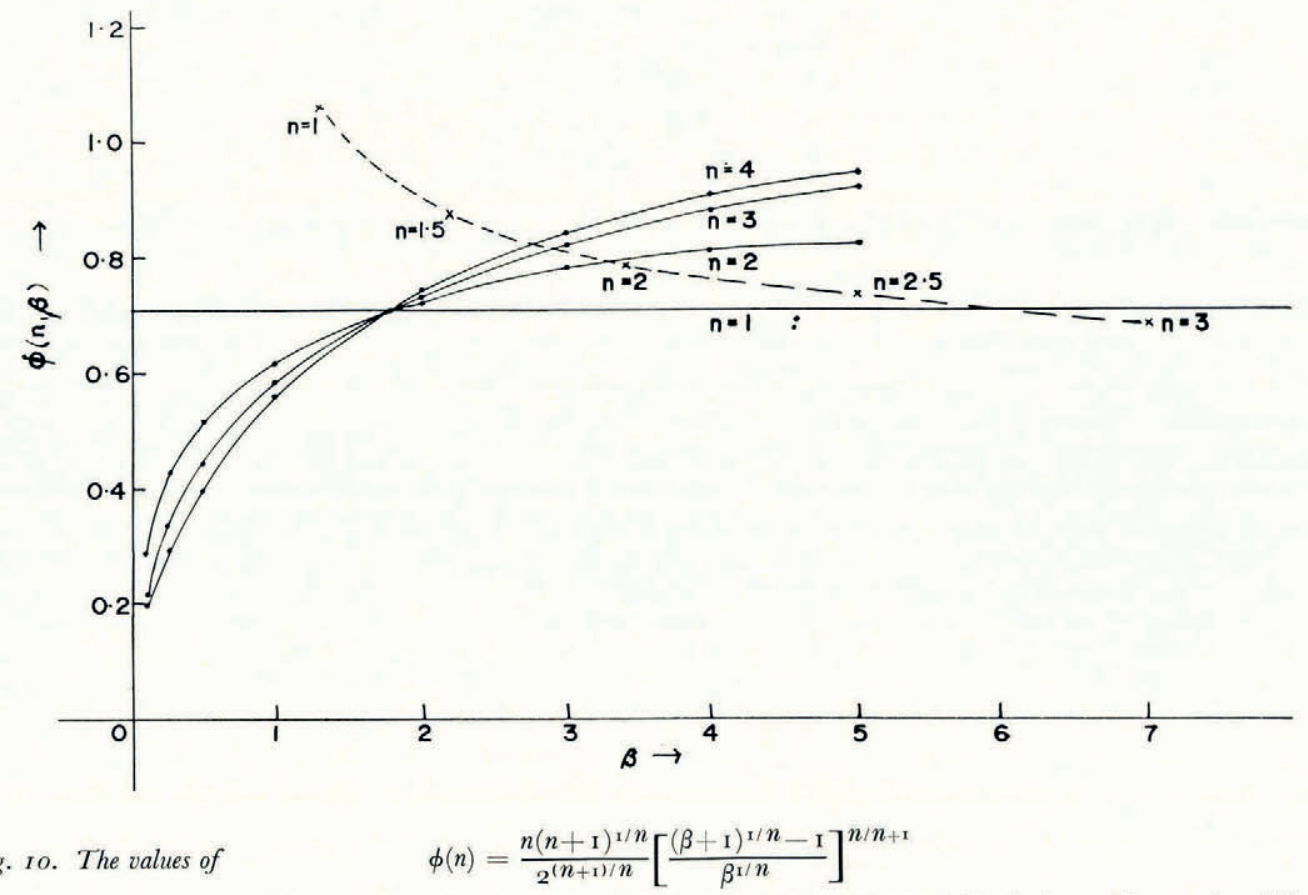

plotted against $\beta$ for different values of $n$. The values of $\phi$ calculated from the ice-shelf velocity profile assuming different values of $n$ and $\beta$, are shown by the dotted line. The correspondence between these curves suggest the best estimate of $n$ for the ice shelf is about 2.0

By differentiating ( 14 ) we find for the velocity gradient

$$
\frac{d V}{d x}=-\frac{V_{\mathrm{o}} \phi}{a}\left[\mathrm{I}-\frac{x}{a} \frac{d a}{d x}+\frac{x}{\phi} \frac{d \phi}{d x}\right] \exp (-\phi x / a) .
$$

This reduces towards the front of the Amery Ice Shelf to

or

$$
\begin{gathered}
\frac{d V}{d x}=-\frac{V_{\mathrm{o}} \phi}{a} \exp (-\phi x / a)=-\frac{V_{\mathrm{C}} \phi}{a} \\
\phi=\frac{a}{V_{\mathrm{C}}} \frac{d V}{d x} .
\end{gathered}
$$

This relation implies that the ratio of the velocity gradient to the velocity due to creep depends on the width $a$ and the flow parameter $n$. 
The first problem is to estimate $V_{\mathbf{C}}$, i.e. to find the proportion of the ice-shelf velocity due separately to the thickness gradient and the creep gradient.

We assume from (4) that

$$
V_{\mathrm{I}} \propto\left[\frac{d H}{d x}\right]^{n} a^{n+\mathbf{I}} .
$$

If we also assume that at $\mathrm{G} 3$, where the strain-rate is small, the velocity is entirely due to the thickness gradient, then we can estimate the corresponding velocity at G I taking into account the change in the values of $a$ and $d H / d x$ from

$$
\frac{V_{\mathrm{IG} \mathrm{II}}}{V_{\mathrm{IG}_{3}}}=\left[\frac{(d H / d x)_{\mathrm{I}}}{(d H / d x)_{3}}\right]^{n}\left[\frac{a_{\mathrm{I}}}{a_{3}}\right]^{n+\mathrm{I}} .
$$

From equations (18) and (19) using the following values:

$$
\begin{array}{rlrl}
a_{\mathrm{1}} & =80 \mathrm{~km} ., & a_{3} & =50 \mathrm{~km} ., \\
\frac{d H}{d x_{1}} & =0.4 \times \mathrm{IO}^{-4}, & \frac{d H}{d x_{3}}=\mathrm{I} .2 \times \mathrm{IO}^{-4}, \\
\frac{d V}{d x} & =6 \times \mathrm{IO}^{-3} \mathrm{yr}^{-1}, & &
\end{array}
$$

we obtain values of $\phi$ for different values of $n$. These are plotted in Figure Io and suggest that the most appropriate value of $n$ is about 2. However, in view of the large percentage error in the small slope measured at GI, the value of $n$ can hardly be specified more precisely than as lying in a range from $\mathrm{I} \cdot 5$ to $2 \cdot 5$.

\begin{tabular}{|c|c|c|c|c|c|c|c|}
\hline $\begin{array}{c}\text { Shear stre } \\
\text { bars }\end{array}$ & & $n$ & & Temper & rature & Ice studied & Reference \\
\hline range & mean & range & mean & ${ }^{\circ} \mathrm{C}$. & & & \\
\hline-10 & & $3-6$ & $4 \cdot 5$ & & -28 & "Byrd" bore-hole closure & Gow (1963) \\
\hline-10 & & & $4 \cdot 2$ & & -30 & $\begin{array}{l}\text { Polycrystalline bubbly } \\
\text { Antarctic ice }\end{array}$ & Mellor (I959) \\
\hline $0 \cdot 5-10$ & & & $3 \cdot 77$ & & -25 & Greenland bore-hole closure & $\begin{array}{l}\text { Hansen and } \\
\quad \text { Landauer (1958) }\end{array}$ \\
\hline I -8 & & & $3 \cdot 17$ & o to & -13 & Polycrystalline ice & Glen (1955) \\
\hline $0 \cdot 5-3 \cdot 7$ & & & 3.07 & & $\sim 0$ & Jungfraufirn bore-hole closure & Nye (1953) \\
\hline $0 \cdot 3-10$ & & & $2 \cdot 96$ & & -5 & $\begin{array}{l}\text { Single crystals (hard glide) and } \\
\text { polycrystalline }\end{array}$ & Butkovich and \\
\hline $0 \cdot 3-2$ & & & $2 \cdot 49$ & & -5 & Single crystal (easy glide) & Landauer (I958) \\
\hline $0 \cdot 2-4$ & & $\begin{array}{l}2 \cdot 3-4 \\
\mathrm{I} \cdot 3-\mathrm{I} \cdot 8\end{array}$ & $\begin{array}{l}3 \cdot 2 \\
1 \cdot 6\end{array}$ & & $\begin{array}{l}-2 \cdot 3 \\
-2 \cdot 3\end{array}$ & $\begin{array}{l}\text { Single crystal (hard) } \\
\text { Single crystal (soft) }\end{array}$ & Steinemann ( 1954$)$ \\
\hline $0 \cdot I-I \cdot 4$ & & & $2 \cdot 8$ & & $\sim 0$ & $\begin{array}{l}\text { Vertical velocity profile Salmon } \\
\text { Glacier }\end{array}$ & Mathews (1959) \\
\hline $0.5-0.8$ & & & $2 \cdot 6$ & & $\sim 0$ & $\begin{array}{l}\text { Vertical velocity profile Blue } \\
\text { Glacier }\end{array}$ & Shreve (I96I) \\
\hline & $\begin{array}{l}>1 \\
<1\end{array}$ & & $\begin{array}{l}3+ \\
1 \cdot 5\end{array}$ & & -8 & $\begin{array}{l}\text { Polycrystalline ice, various } \\
\text { orientations }\end{array}$ & Vyalov (1958) \\
\hline $0 \cdot 01-1$ & $\begin{array}{l}>0 \cdot 2 \\
<0.2\end{array}$ & & $\begin{array}{l}4 \cdot 5 \\
\text { I }\end{array}$ & & $\sim 0$ & $\begin{array}{l}\text { Velocity profiles Saskatchewan } \\
\text { Glacier }\end{array}$ & Meier ( 1960$)$ \\
\hline $0 \cdot I-0 \cdot 75$ & & & $\mathrm{I} \cdot 5$ & & $\sim 0$ & $\begin{array}{l}\text { Vertical velocity profile } \\
\text { Jungfraufirn }\end{array}$ & $\begin{array}{l}\text { Gerrard and others } \\
\text { (1952) }\end{array}$ \\
\hline $0 \cdot 0 \mathrm{I}-0 \cdot \mathrm{I}$ & & & $1 \cdot 0$ & $-\mathrm{I} \cdot 3$ to & $-18 \cdot 9$ & $\begin{array}{l}\text { Polycrystalline, artificial and } \\
\text { glacier ice }\end{array}$ & $\begin{array}{l}\text { Butkovich and } \\
\text { Landauer (196o) }\end{array}$ \\
\hline
\end{tabular}

In Table IV are listed the values of $n$ found by various workers with the associated stress ranges. Although there is much variation due to such factors as ice type and crystal orientation the general conclusion seems to be that for low shear stress $(0 . \mathrm{I}-0.5$ bar $)$ the value of $n \approx \mathrm{I}$ and that this value increases with stress, rapidly in the region of 0.75 bar, to values of $2,3,4, \ldots$, as the shear stress increases from I to io bars.

Table IV. Values of the Exponent in the Flow Law of Ice 
Robin (I958) showed that the maximum stress difference $\left(\sigma_{z}-\sigma_{x}\right)$ in the Maudheim ice shelf was about I .8 bars. This implies a maximum shear stress of 0.9 bar. We shall now consider the shear stress in the Amery Ice Shelf.

\subsection{The shear stress in the ice shelf}

Near the centre of the ice shelf we can neglect the effect of shear across the ice shelf and so will consider first the shear stress associated with "Weertman creep". From Weertman (1957) the shear stress $\tau$ is related to the $x$ and $z$ principal stresses by

$$
\tau=\frac{\sigma_{z z}-\sigma_{x x}}{2}
$$

Since we have considered the creep rate as constant with depth, the relevant shear stress will be the mean value through the ice-shelf thickness. Denoting the mean of a variable over the depth by a bar over that variable, we have near the front of the ice shelf, following Weertman,

$$
\begin{gathered}
\bar{\sigma}_{x x}=\frac{\mathrm{I}}{H} \int_{0}^{H\left(\bar{\rho}_{\mathrm{i}} / \rho_{\mathrm{w}}\right)} g \rho_{\mathrm{w}}\left[H \frac{\bar{\rho}_{\mathrm{i}}}{\rho_{\mathrm{w}}}-z\right] d z=-\frac{1}{2} \bar{\rho}_{\mathrm{i}} g H\left[\frac{\bar{\rho}_{\mathrm{i}}}{\rho_{\mathrm{w}}}\right], \\
\bar{\sigma}_{z z}=-\frac{\mathrm{I}}{H} \int_{0}^{H} \bar{\rho}_{\mathrm{i}} g(H-z) d z=-\frac{1}{2} \bar{\rho}_{\mathrm{i}} g H, \\
\bar{\tau}=\frac{1}{4} \bar{\rho}_{\mathrm{i}} g H\left[\mathrm{I}-\frac{\bar{\rho}_{\mathrm{i}}}{\rho_{\mathrm{w}}}\right] .
\end{gathered}
$$

therefore

Using $\quad \bar{\rho}_{\mathrm{i}}=0.85 \mathrm{~g} . \mathrm{cm} .{ }^{-3}, \quad \rho_{\mathrm{w}}=\mathrm{I} .03 \mathrm{~g} . \mathrm{cm} .^{-3}, \quad g=980 \mathrm{~cm} . \mathrm{sec} .^{-2}, \quad H=2.0 \times \mathrm{IO}^{4} \mathrm{~cm} .$, we obtain

$$
\bar{\tau}=0.73 \text { bar. }
$$

As the creep rate decreases going inland from the ice front, $\sigma_{x x} \rightarrow \sigma_{z z}$ and hence $\bar{\tau} \rightarrow 0$. Thus the shear stress in the centre of the ice shelf is less than $\frac{3}{4}$ bar over the whole length of the ice shelf.

The maximum shear stress across the ice shelf occurs at the edge, $80 \mathrm{~km}$. from the centre at GI. The value of this shear stress is given by $\bar{\tau}=a(d p / d x)$.

Now $d p / d x$ is determined below as $2.5 \mathrm{bar} / \mathrm{r}$ oo $\mathrm{km}$., hence we obtain $\tau=2$ bars. Since the variation in shear stress across the ice shelf is linear, the average shear stress across the ice shelf in the region of $\mathrm{G}$ I is I bar. These values of shear stress are hence compatible with the effective range of the flow parameter $n$ calculated above.

\subsection{Value of parameter $B$}

From equation (7) we have

$$
B\left\{\left[\frac{(n+\mathrm{I}) V}{2 a}\right]^{\mathrm{I} / n} \frac{\mathrm{I}}{a}-\frac{2}{n} K^{(\mathrm{I} / n)-\mathrm{I}} \frac{d K}{d x}\right\}=\frac{\rho g}{2} \frac{\partial H}{\partial x} .
$$

Using $n=2$, and substituting the values measured at G I as follows: $a=80 \mathrm{~km} .\left(8 \times \mathrm{IO}^{6} \mathrm{~cm}\right.$. $)$, $V=800 \mathrm{~m} . \mathrm{yr}^{-1}\left(2.5 \times 1 \mathrm{I}^{-3} \mathrm{~cm} . \mathrm{sec}^{-1}\right), K=6 \times 10^{-3} \mathrm{yr}^{-1}\left(\mathrm{I} .9 \times \mathrm{Io}^{-10} \mathrm{sec}^{-1}\right), d K / d x=$ $=2 \times \mathrm{ro}^{-17} \mathrm{~cm} .^{-1} \mathrm{sec}^{-1}, \quad \partial H / d x=5.7 \times 0.4 \times \mathrm{IO}^{-4}, \quad \rho=0.85 \mathrm{~g} . \mathrm{cm} .^{-3}$, we obtain an estimate for $B$, viz.

$$
B=0.9 \mathrm{I} \times \mathrm{IO}^{\mathrm{II}} \text { dyn. } \mathrm{cm} \cdot{ }^{-2} \mathrm{sec} .^{-\frac{1}{2}} \text {. }
$$

In order to compare this value of the flow parameter $B$ with the results of other determina- 
tions, e.g. the values obtained by Glen (I955), it is first necessary to convert to the same units, using the same value of $n$. Following Shumskiy (I96I)

$$
\left.\begin{array}{rl}
{\left[\frac{B_{2}}{\tau}\right]^{n_{2}}} & =\left[\frac{B_{1}}{\tau}\right]^{n_{1}}, \\
B_{2} & =B_{\mathrm{x}} n_{1} / n_{2} \tau^{\left(n_{2}-n_{1}\right) / n_{2} .}
\end{array}\right\}
$$

We set $n_{2}=3, \tau=\mathrm{IO}^{6}$ dyn. cm..$^{-2}$. For the Amery Ice Shelf at G I we use $B_{\mathrm{I}}=0.9 \mathrm{I} \times \mathrm{IO}^{1 \mathrm{II}}$ dyn. cm..$^{-2}$ sec..$^{-\frac{1}{2}}$ and $n_{\mathrm{I}}=2$ to obtain

$$
B_{2}=2.0 \times 10^{9} \text { dyn. } \mathrm{cm} .^{-2} \text { sec. } .^{-1} \text {. }
$$

The values from Glen (1955, p. 528) have been converted to the corresponding shear values by the method of Nye (I953, p. 486) and then to c.g.s. units with $n=3$. These values of $B$ have then been plotted against temperature in Figure II, together with similar values obtained by extrapolation of the curves of Steinemann (I958, p. I89) to a shear stress of I bar. The value of $2.0 \times 10^{9}$ for the Amery Ice Shelf has been plotted against $-16^{\circ} \mathrm{C}$., which is the mean temperature calculated for the Amery Ice Shelf at G I assuming that the temperature-depth profile has the same shape as that of the Ross Ice Shelf at "Little America". The agreement with the laboratory values is quite close, considering a possible error of \pm 20 per cent, due largely to the possible error in the measured ice-shelf slope.

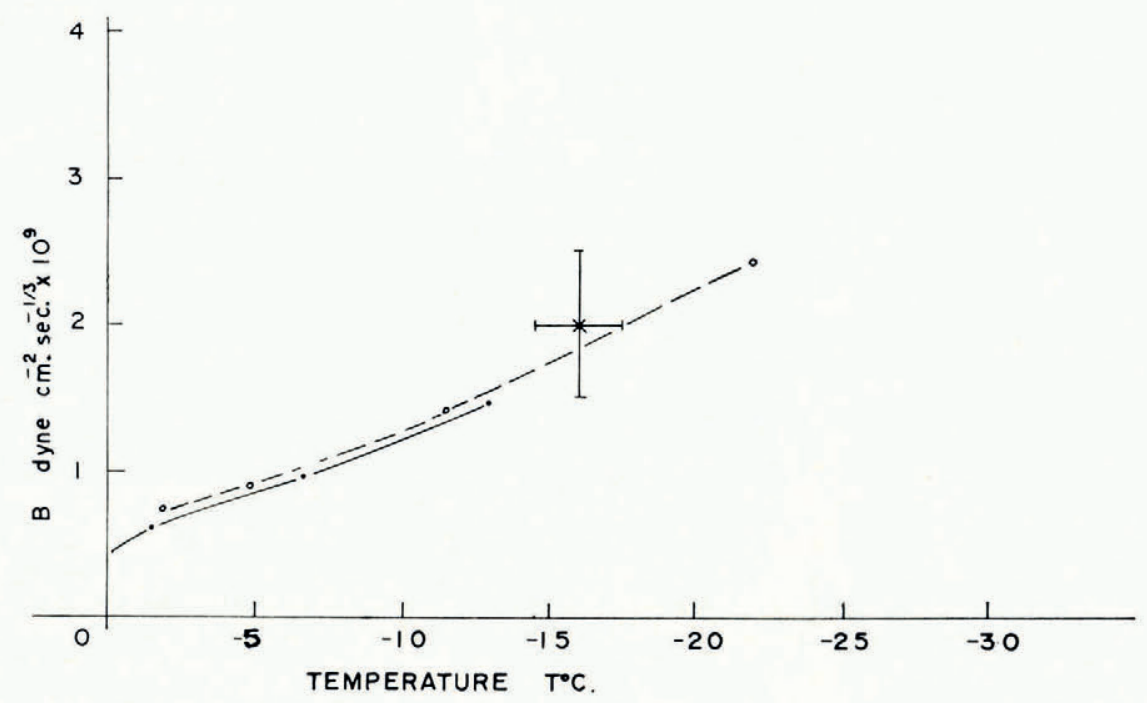

Fig. II. The value of the flow parameter $B$ from the flow law for ice $\dot{\epsilon}=(\tau / B)^{n}$ calculated for different temperatures from the laboratory measurements of ice creep by Glen $(\bullet)$ and Steinemann $(O)$, and converted to shear values in units of dyn. $\mathrm{cm} .^{-2}$ sec..$^{-1}$. The value calculated from the velocity profile of the Amery Ice Shelf at $\mathrm{G}$ I has been plotted against a temperature of $-I 6^{\circ} \mathrm{C}$. - the calculated mean temperature of the ice shelf at $\mathrm{GI}$

\subsection{Velocity profile across the ice shelf}

We first require the pressure gradient, at G I say. This can be determined from

$$
\frac{d p}{d x}=\frac{B}{a}\left(\frac{n+\mathrm{I}}{2 a} V\right)^{\mathrm{I} / n}
$$

which, using the same values at $\mathrm{G}_{\mathrm{I}}$ as those in section 3.4 , yields $d p / d x=0.25$ dyn. $\mathrm{cm} .{ }^{-3}=$ $=2.5 \mathrm{bar} / \mathrm{I} 00 \mathrm{~km}$. 
Having determined the flow parameters $n, B$, and the pressure gradient at G I we can now calculate an ideal velocity profile across the ice shelf from

$$
V_{\mathrm{m}}-V=\frac{y^{n+1}}{n+\mathrm{I}} \frac{2}{B^{n}}\left(\frac{d p}{d x}\right)^{n}
$$

where $V_{\mathrm{m}}$ is the maximum velocity at the centre, $V$ is the velocity at distance $y$ from the centre, $d p / d x=0.25$ dyn. cm. $.^{-3}, B=0.9 \mathrm{I} \times 1 \mathrm{IO}^{\mathrm{II}}$ dyn. $\mathrm{cm} \cdot .^{-2} \mathrm{sec} .^{-\frac{1}{2}}$ and $n=2$. This gives the following values:

Putting $V_{\mathrm{m}}=800 \mathrm{~m} . \mathrm{yr}^{-1}$

$$
\begin{aligned}
& y=0 \quad 20 \quad 40 \quad 60 \quad 80 \mathrm{~km} . \\
& V_{\mathrm{m}}-V=\quad \text { o } \quad \text { I2 } \quad \text { I00 } 340 \quad 800 \mathrm{~m} \cdot \mathrm{yr}^{-\mathrm{I}}
\end{aligned}
$$

$$
V=800 \quad 788 \quad 700 \quad 460 \quad \text { o m. yr. } .^{-1}
$$

This velocity profile is illustrated in Figure 12 together with profiles resulting from taking $n$ equal to $\mathrm{I}$ and 3 .

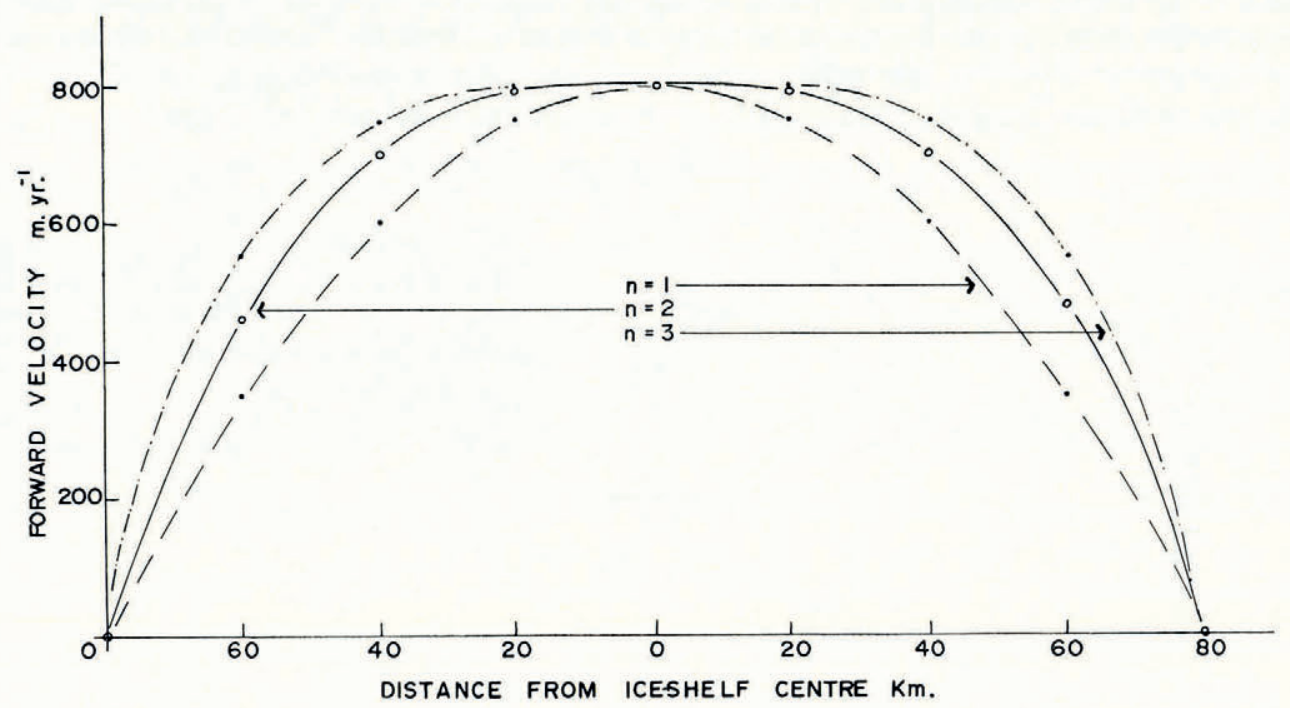

Fig. 12. The calculated ideal velocity profile across the Amery Ice Shelf at $\mathrm{G}$ I using the calculated flow parameters $n$ and $B$ is shown together with the corresponding profiles that would apply for $n=I$ and $n=3$. The transverse shear strain is seen to be small at the centre of the ice shelf but increases towards the margins. Large shear crevasses were observed on the Amery Ice Shelf between $30 \mathrm{~km}$. from the centre and the margin

An interesting result which follows from this profile is that there is very little horizontal shear in the centre of the ice shelf but considerable shear between about $30 \mathrm{~km}$. from the centre and the edge. This is in agreement with the location of the observed shear crevasses on the ice shelf. The curve is also in good agreement with the transverse velocity gradient measured by Landon-Smith from a strain grid at $\mathrm{E}(6 \mathrm{o} \mathrm{km}$. from the centre) of $16.7 \mathrm{~m} . / \mathrm{km}$. yr.

\section{Energy Considerations}

For a rapidly deforming ice shelf the following questions arise: (i) does the potential energy released have any appreciable effect on the thermal regime of the ice shelf: and (ii) is the increase of kinetic energy a significant factor in the energy budget. These questions are answered by the following considerations. 


\section{I. Potential energy}

Consider an iceberg that spreads out uniformly without change of volume. The change in potential energy associated with a decrease $\Delta H$ in thickness arises solely from the displacement of the centres of gravity of the displaced water and the ice, and per unit area is given by:

$$
\Delta E_{\mathrm{p}}=\frac{g H \Delta H \rho_{\mathrm{i}}}{2 \rho_{\mathrm{w}}}\left(\rho_{\mathrm{w}}-\rho_{\mathrm{i}}\right)
$$

where $g$ is acceleration due to gravity, $H$ is ice thickness, $\rho_{\mathrm{i}}$ is the mean density of the ice, and $\rho_{\mathrm{w}}$ is the mean density of the water.

We now express $\Delta H$ in terms of horizontal creep rates $\dot{\epsilon}_{x}$ and $\dot{\epsilon}_{y}$, per unit time

$$
\Delta H=H\left(\dot{\epsilon}_{x}+\dot{\epsilon}_{y}\right) .
$$

For the Amery Ice Shelf $\dot{\epsilon}_{y}$ was only a small fraction of $\dot{\epsilon}_{x}$, hence we write

$$
\dot{\epsilon}_{x}+\dot{\epsilon}_{y}=\gamma \dot{\epsilon}_{x}=\gamma \frac{d V}{d x} \text { with } \quad \gamma \approx \text { I.I. }
$$

Then

$$
\Delta E_{\mathrm{p}}=\frac{1}{2} g H^{2} \rho_{\mathrm{i}} v \gamma \frac{d V}{d x}
$$

where $v=\left(\mathrm{I}-\rho_{\mathrm{i}} / \rho_{\mathrm{w}}\right)$. We now integrate $\Delta E_{\mathrm{p}}$ over the ice shelf and write $\bar{V}$ for the mean forward velocity across the ice shelf at distance $x$ from the front and $\bar{h}, 2 \bar{a}$ for the mean thickness and width. Then

or

$$
\begin{aligned}
& \frac{d E_{\mathrm{p}}}{d t}=g \bar{H}^{2} \bar{a} \rho_{\mathrm{i}} v \gamma \int_{0}^{x} \frac{d \bar{V}}{d x} d x, \\
& \frac{d E_{\mathrm{p}}}{d t}=g \bar{H} \bar{a} \rho v \gamma\left(\bar{V}_{\mathrm{o}}-\bar{V}\right) .
\end{aligned}
$$

Putting $H=2 \times \mathrm{IO}^{4} \mathrm{~cm}$. and $\bar{a} \sim 7 \times \mathrm{IO}^{6} \mathrm{~cm}$., we obtain

$$
\frac{d E_{\mathrm{p}}}{d t} \approx 4 \times \mathrm{IO}^{\mathrm{I} 4} \text { cal. } \mathrm{yr} .^{-\mathrm{I}} \text {. }
$$

The ice-shelf area is $4.5 \times 10^{14} \mathrm{~cm}^{2}$. This indicates that the average heating produced by the deformation is small, less than I cal. $\mathrm{cm} \cdot{ }^{-2} \mathrm{yr} .^{-1}$ average and less than Io cal. $\mathrm{cm}^{-2} \mathrm{yr}^{-1}$ maximum. Hence the potential energy loss due to creep will have negligible effect on the vertical temperature profile through the ice shelf.

\subsection{Kinetic energy}

The increase in kinetic energy per year may be obtained from

which gives

$$
\frac{d E_{\mathrm{k}}}{d t}=2 \rho H a \int_{0}^{x} V \frac{d V}{d x} d x
$$

$$
\frac{d E_{\mathrm{k}}}{d t}=\frac{2}{3} \rho H a\left(V^{3}-V_{\mathrm{o}}^{3}\right) .
$$

After substituting the velocities and the mean values of the other parameters for the ice shelf it is found that the change in kinetic energy is many orders smaller than the change in potential energy. Hence in energy and heat budget calculations both the internal heat produced, and the gain in kinetic energy, may be neglected. 


\section{IGE-SHeLf Regime}

\section{I. Variation of "thinning rates" along ice shelf}

Relations for the mass regime of ice-shelves have been discussed by Crary (I96 I, I964) and Shumskiy and Zotikov (1963, 1965). First these authors have used different approaches in calculating the effect and densification and compaction on the change in ice-shelf thickness. The following procedure will be adopted here.

If Sorge's law is assumed to apply (i.e. the density profile from the surface downwards retains the same form with time) then it follows from an integration of Bader's (1954) expression

$$
S=-\frac{A_{\mathrm{s}}}{\rho^{2}} \frac{d \rho}{d z}
$$

for the settling rate $S$ of snow at depth $z$ with density $\rho$, that the total amount of compaction is equal to the difference in thickness between the snow accumulation at surface density and the corresponding thickness of snow compressed to ice, thus the total compaction is

$$
\int_{\rho_{\mathrm{s}}}^{\rho_{\mathrm{1}}}-\frac{A_{\mathrm{s}}}{\rho^{2}} \frac{d \rho}{d z} d z=A_{\mathrm{S}}\left(\frac{\mathrm{I}}{\rho_{\mathrm{S}}}-\frac{\mathrm{I}}{\rho_{\mathrm{i}}}\right)
$$

where $A_{\mathrm{S}}$ is the mass of snow accumulation per unit area, $\rho_{\mathrm{S}}$ is the surface snow density, and $\rho_{\mathrm{i}}$ is the ice density at the base of the ice shelf. This means that the effect of densification can be neglected if the thickness due to the accumulating snow is calculated using $A=A_{\mathrm{s}} / \rho_{\mathrm{i}}$ instead of $A_{\mathrm{s}} / \rho_{\mathrm{s}}$.

Secondly, if the ice-shelf thickness is changing in time, then it is not valid to calculate melt rate from the equation of balance. We have for the rate of change in the ice-shelf thickness $H$ in a given position with time

$$
\frac{\partial H}{\partial t}=A-M-\left(\dot{\epsilon}_{x}+\dot{\epsilon}_{y}\right) H+V \frac{\partial H}{\partial x}
$$

where $A$ is the surface accumulation rate in centimetres of ice per year, $M$ is the bottom melt rate in centimetres of ice per year, $\left(\dot{\epsilon}_{x}+\dot{\epsilon}_{y}\right) H$ is the change in thickness due to spreading, $V$ the ice-shelf velocity at the position, and $\partial H / \partial x$ the longitudinal rate of change of ice-shelf thickness at the position. The corresponding mass change would be given by

$$
\bar{\rho} \frac{\partial H}{\partial t}=A \rho_{\mathrm{i}}-M \rho_{\mathrm{i}}-\bar{\rho}\left(\dot{\epsilon}_{x}+\dot{\epsilon}_{y}\right) H+\bar{\rho} V \frac{\partial H}{\partial x} .
$$

Because of the small slope of the Amery Ice Shelf the variation of the density profile along the ice shelf is neglected. Actually $\partial \bar{\rho} / \partial x$ does vary slightly, not because $\partial \rho / \partial x$ is appreciable but because of the thickness gradient and the dense ice being at the base of the ice shelf.

In equation (30) above the two unknown values for the Amery Ice Shelf are $\partial H / \partial t$ and $M$. Crary (I96I) obtained estimates of bottom melting for the Ross Ice Shelf from the vertical temperature profile, but as these data are not available for the Amery Ice Shelf the values of

$$
\left(\frac{\partial H}{\partial t}+M\right)=A-\left(\dot{\epsilon}_{x}+\dot{\epsilon}_{y}\right) H+V \frac{\partial H}{\partial x}
$$

are evaluated and listed in Table $\mathrm{V}$ for the three positions along the Amery Ice Shelf centreline, together with the values at the fronts of the Ross Ice Shelf at "Little America" (Crary, I96r) and the Maudheim ice shelf (Swithinbank, I957[a], I957[b], I958, [1962]; Robin I958).

From the results of Table $\mathrm{V}$ it can be seen that the flatter, more rapidly spreading Amery Ice Shelf would need to accrue ice at its base in the region of G I at the rate of $90 \mathrm{~cm}$. ice yr. ${ }^{-\mathrm{I}}$ 
Table V. Ice-Shelf Thinning and Melt Rates

\begin{tabular}{|c|c|c|c|c|c|}
\hline & \multicolumn{2}{|l|}{ "Little } & \multicolumn{3}{|c|}{ Amery } \\
\hline & America" & Maudheim & GI & G2 & G3 \\
\hline$A_{\mathrm{s}} \mathrm{g} \cdot \mathrm{cm} .^{-2} \mathrm{yr}^{-1}$ & 24 & 40 & 35 & I 8 & II \\
\hline$A \mathrm{~cm}{\text {. ice } \mathrm{yr} .^{-1}}^{-1}$ & 27 & 44 & 39 & 20 & 12 \\
\hline$\dot{\epsilon}_{x} \mathrm{IO}^{-4} \mathrm{yr} .^{-1}$ & $8 \cdot I$ & $5 \cdot 5$ & 60 & I 7 & 5 \\
\hline$\dot{\epsilon}_{y} 1 \mathrm{O}^{-4} \mathrm{yr}^{-1}$ & $12 \cdot 9$ & $13 \cdot 8$ & 8 & I & I \\
\hline$h \times \mathrm{IO}^{4} \mathrm{~cm}$ & $0 \cdot 43$ & $0 \cdot 37$ & $0 \cdot 3^{8}$ & $0 \cdot 4^{2}$ & $0 \cdot 5^{2}$ \\
\hline$H \times 10^{4} \mathrm{~cm}$. & $2 \cdot 57$ & $2 \cdot 10$ & $2 \cdot 20$ & $2 \cdot 45$ & $3 \cdot 30$ \\
\hline$\alpha \times 10^{-4}$ & $6 \cdot 1$ & 5 & $0 \cdot 4$ & 0.6 & $I \cdot 2$ \\
\hline$\partial H / \partial x \times 10^{-4}$ & $36 \cdot 6$ & 30 & $2 \cdot 4$ & $3 \cdot 6$ & $7 \cdot 2$ \\
\hline$V \times 1 \mathrm{O}^{4} \mathrm{~cm} \cdot \mathrm{yr}^{-1}$ & $2 \cdot 55$ & $3 \cdot 0$ & $8 \cdot 0$ & $5 \cdot 0$ & $4 \cdot I$ \\
\hline$\rho_{\mathrm{s}} \mathrm{g} \cdot \mathrm{cm} \cdot{ }^{-3}$ & $0 \cdot 35$ & - & 一 & - & - \\
\hline $\bar{\rho} \mathrm{g} \cdot \mathrm{cm} \cdot^{-3}$ & 0.85 & - & - & 一 & 一 \\
\hline$\left(\dot{\epsilon}_{x}+\dot{\epsilon}_{y}\right) H \mathrm{~cm} . \mathrm{yr}^{-1}$ & 54 & $4^{I}$ & ${ }^{\mathrm{I}} 5^{\mathrm{O}}$ & 44 & 20 \\
\hline$V \partial H / \partial x \mathrm{~cm} . \mathrm{yr}^{-1}$ & 93 & 60 & I9 & I 8 & $3^{\circ}$ \\
\hline$(M+\partial H / \partial t) \mathrm{cm} \cdot \mathrm{yr}^{-1}$ & 66 & 63 & $-9^{2}$ & -6 & 22 \\
\hline
\end{tabular}

to remain in balance. In view of the melt-rate and current flow calculations of Shumskiy and Zotikov (1963) this would seem unlikely and instead melting may even be taking place. Hence we conclude that the ice shelf may be thinning at about $\mathrm{I} \mathrm{m}$./yr. at this position. This thinning rate would decrease inland so that beyond a certain point the ice shelf is probably becoming thicker. Hence we conclude that the ice shelf is in a process of continual change of form.

\subsection{Advance of ice-shelf front}

The Amery Ice Shelf front has not been in a state of continual balance with small icebergs breaking off each year to compensate for the forward motion. On the contrary it may be seen from Figure 13 that the front has been gradually advancing, and spreading out, over a period of about $4{ }^{0}-50 \mathrm{yr}$., with increasing speed and little change in form due to iceberg formation until a major break out of about a fifth of the ice-shelf area occurred in 1963 . After this it is expected that such a process may recommence.

This pattern of change supports the idea of changing form deduced from the thinning rates above. Over a period of $40 \mathrm{yr}$. thinning at the rate of $\mathrm{I} \mathrm{m}$. $\mathrm{yr}^{-\mathrm{I}}{ }^{\mathrm{r}}$ would amount to $40 \mathrm{~m}$. which would give a resulting change in surface elevation of about $7 \mathrm{~m}$. The rate of change of thickness, however, would not be constant with time because it would cause an increased longitudinal slope which could then give rise to decreased thinning rates.

For the flat central section of the Ross Ice Shelf, Crary and others (1962, p. 102) showed that the condition of balance and melting implied negative strain-rates of the order $\mathrm{IO}^{-3} \mathrm{yr}^{-1}$ in that region. Zumberge ( 1964 ) assumed a steady-state profile to calculate the amount of melting or freezing at the base. He found the magnitude of bottom melting would have to decrease exponentially with distance from the seaward edge of the shelf, to a zone between 40 and $100 \mathrm{~km}$. southward, beyond which increasing bottom freezing would be required for balance. An alternative explanation for both Crary's and Zumberge's results could be that the ice shelf is at present thinning, and this possibility should be kept in mind in considering the regime of the Ross Ice Shelf in the same way as has been done here for the Amery Ice Shelf.

The next re-survey of the Amery Ice Shelf by the A.N.A.R.E. is planned for 1967. In addition to new measurements to be carried out, re-surveys of the original 1963 markers should greatly reduce the errors in the present estimates of velocity, velocity gradient and elevation profile. This could then provide a basis for determining the change of the ice-shelf regime with time to test the hypothesis of steady-state conditions. 


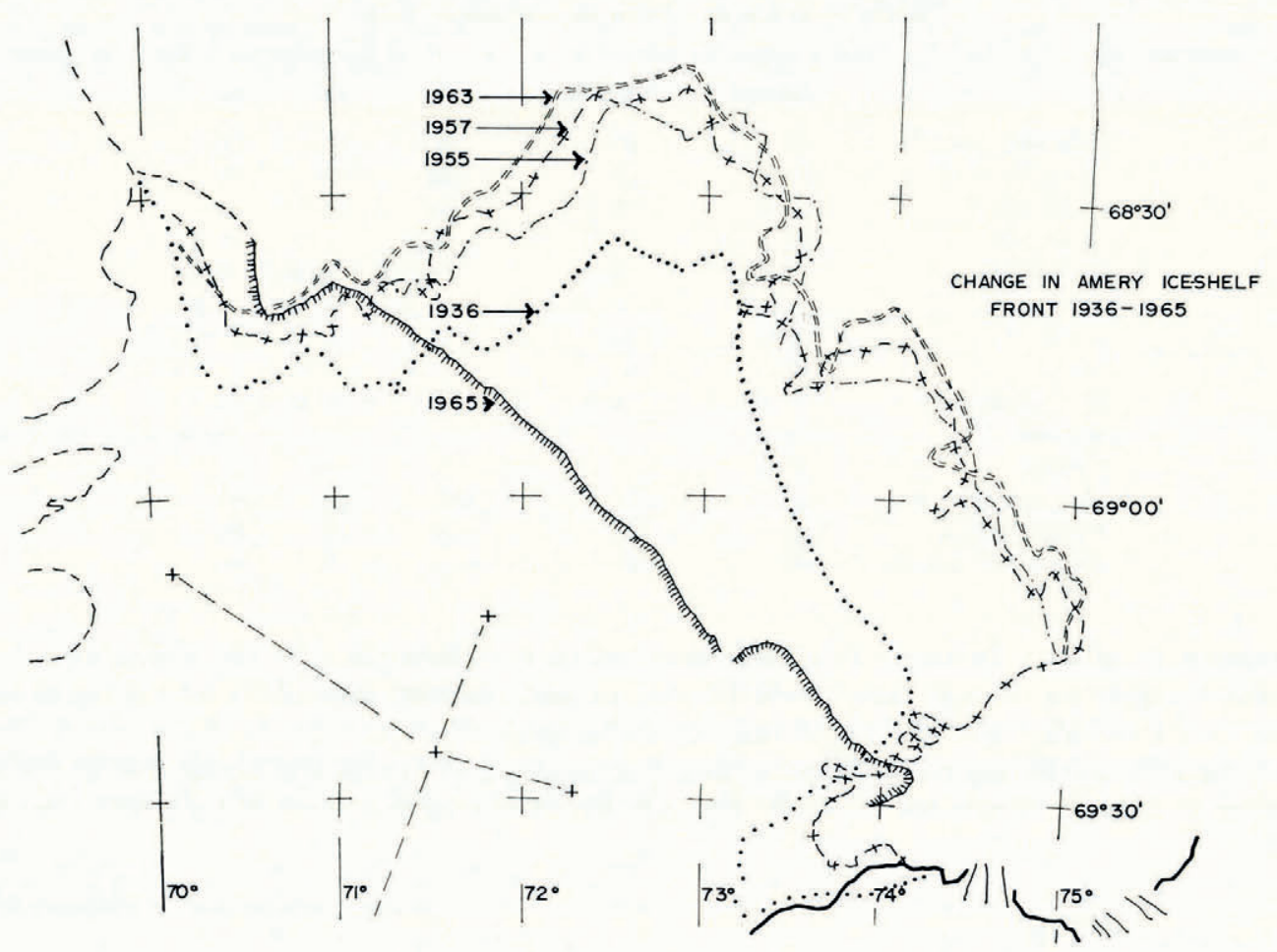

Fig. 13. The position of the Amery Ice Shelf front plotted by different expeditions is shown as follows:

$$
\begin{array}{ll}
\text { I936 } & \text { Lars Christensen Expedition } \\
\text { I955 A.N.A.R.E. } \\
\text { I957 Soviel Antarctic Expedition } \\
\text { I963 } \\
\text { I965.A.R.E. } \\
\text { A.N.A.R.E. }
\end{array}
$$

The errors in positioning are estimated at $\pm 3 \mathrm{~km}$. but in spite of this the general forward movement and spreading out is significant. A position on the front was astrofixed by the Soviet Expedition in 1957 and a repeat of this by A.N.A.R.E. in 1963 gave a velocity estimate at the front of $1,500 \pm 300 \mathrm{~m} \cdot y \mathrm{r} .^{-1}$. The large break out of the ice shelf occurred later in 1963

\section{Acknowledgements}

The author gratefully acknowledges the help and support by all the members of the A.N.A.R.E. who have taken part in the ice-shelf project. Mr. I. H. Landon-Smith provided the results of his 1962 work and made many valuable suggestions for the later work. Mr. E. R. Wishart conducted the extensive I 963 survey that provided the basis for the 1964 remeasurements. Mr. G. McKinnon provided the map of Figure I3. Dr. U. Radok of the Meteorology Department, University of Melbourne, advised on and co-ordinated the programmes, and critically reviewed the manuscript. The paper is published with the permission of the Director of the Australian Antarctic Division.

MS. received 4 January 1966

\section{REFERENCES}

Bader, H. 1954. Sorge's law of densification of snow on high polar glaciers. fournal of Glaciology, Vol. 2, No. I5, p. 319-23.

Budd, W. 1965. Glaciological survey of the Amery Ice Shelf. Antarctic (Wellington, N.Z.), Vol. 4, No. 3, p. I $5^{8-59 .}$ 
Butkovich, T. R., and Landauer, J. K. 1958. The flow law for ice. Union Géodésique et Géophysique Internationale. Association Internationale d'Hydrologie Scientifique. Symposium de Chamonix, 16-24 sept. 1958, p. 318-27.

Butkovich, T. R., and Landauer, J. K. i96o. Creep of ice at low stresses. U.S. Snow, Ice and Permafrost Research Establishment. Research Report 72.

Crary, A. P. 1961. Glaciological studies at Little America station, Antarctica, 1957 and 1958. IG Y Glaciological Report Series (New York, IGY World Data Center A, Glaciology), No. ,5.

Crary, A. P. 1964. Melting at the ice-water interface, "Little America" station. Fournal of Glaciology, Vol. 5, No. 37 , p. 129-30. [Letter.]

Crary, A. P., and Chapman, W. H. 1963. Additional glaciological measurements at the abandoned Little America station, Antarctica. Journal of Geophysical Research, Vol. 68, No. 21, p. 6064-65.

Crary, A. P., and others. 1962. Glaciological studies of the Ross Ice Shelf, Antarctica, I957-1960, by A. P. Crary, E. S. Robinson, H. F. Bennett, and W. W. Boyd, Jr. IGY Glaciological Report Series (New York, IGY World Data Center A, Glaciology), No. 6.

Gerrard, J. A. F., and others. I952. Measurement of the velocity distribution along a vertical line through a glacier, by J. A. F. Gerrard, M. F. Perutz and A. Roch. Proceedings of the Royal Society, Ser. A, Vol. 2 I3 $_{3}$, No. III5, p. $546-58$.

Glen, J. W. 1955. The creep of polycrystalline ice. Proceedings of the Royal Society, Ser. A, Vol. 228, No. I175, p. $519-38$.

Gow, A. J. 1963. Results of measurements in the 309 meter bore hole at Byrd station, Antarctica. Fournal of Glaciology, Vol. 4, No. 36, p. $77 \mathrm{I}-84$.

Hansen, B. L., and Landauer, J. K. 1958. Some results of ice cap drill hole measurements. Union Géodésique et Géophysique Internationale. Association Internationale d'Hydrologie Scientifique. Symposium de Chamonix, I6-24 sept. 1958 , p. $3{ }^{1} 3^{-1} 7$.

Jaeger, J. C. 1956. Elasticity fracture and flow. London, Methuen.

Landon-Smith, I. H. [1964.] Bericht über glaziologische Untersuchungen des Amery-Schelfeises in der Antarktis. Polarforschung, Bd. 5, Jahrg. 33, Ht. I-2, 1963, p. 190-91.

Landon-Smith, I. H. Unpublished. Glaciological studies at Mawson and on the Amery Ice Shelf I962. [M.Sc. thesis submitted to Meteorology Department, University of Melbourne, i 965.$]$

Mathews, W. H. 1959. Vertical distribution of velocity in Salmon Glacier, British Columbia. Journal of Glaciology, Vol. 3, No. 26. p. 448-54.

Meier, M. F. 1960. Mode of flow of Saskatchewan Glacier, Alberta, Canada. U.S. Geological Survey. Professional Paper $35^{\mathrm{I}}$.

Mellor, M. 1959. Creep tests on Antarctic glacier ice. Nature, Vol. 184, No. 4687, p. 7 I 7.

Nye, J. F. 1952. The mechanics of glacier flow. Journal of Glaciology, Vol. 2, No. 12, p. 82-93.

Nye, J. F. 1953. The flow law of ice from measurements in glacier tunnels, laboratory experiments and the Jungfraufirn borehole experiment. Proceedings of the Royal Society, Ser. A, Vol. 219, No. 1 139, p. 477-89.

Robin, G. de Q. 1958. Glaciology. III. Seismic shootings and related investigations. Norwegian-British-Swedish Antarctic Expedition, 1949-52. Scientific Results (Oslo, Norsk Polarinstitutt), Vol. 5 .

Shumskiy, P. A. r961. On the theory of glacier motion. Union Géodésique et Géophysique Internationale. Association Internationale d'Hydrologie Scientifique. Assemblée générale de Helsinki, 25-7-6-8 1960 . Colloque sur la glaciologie antarctique, p. $142-49$.

Shumskiy, P. A., and Zotikov, I. A. 1963 . On the bottom melting of the Antarctic ice shelves. Union Géodésique et Géophysique Internationale. Association Internationale d'Hydrologie Scientifique. Assemblée générale de Berkeley, $19^{-8}-3^{1-8}$ 1963. Commission des Neiges et des Glaces, p. 225-31.

Shumskiy, P. A., and Zotikov, I. A. 1965. Regime of the Ross Ice Shelf, "Little America" station. Journal of Glaciology, Vol. 5, No. 4I, p. 759-6o. [Letter.]

Shreve, R. L. 1961. The borehole experiment on Blue Glacier, Washington. Union Géodésique et Géophysique Internationale. Association Internationale d'Hydrologie Scientifique. Assemblée générale de Helsinki, 25-7-6-8 196o. Commission des Neiges et Glaces, p. 530-31.

Steinemann, S. 1954. Results of preliminary experiments on the plasticity of ice crystals. Fournal of Glaciology, Vol. 2, No. 16, p. 404-13.

Steinemann, S. I958. Résultats experimentaux sur la dynamique de la glace et leurs correlations avec le mouvement et la pétrographie des glaciers. Union Géodésique et Géophysique Internationale. Association Internationale d'Hydrologie Scientifique. Symposium de Chamonix, I6-24 sept. 1958, p. 184-98.

Swithinbank, C. W. M. r957[a]. Glaciology. I. The morphology of the ice shelves of western Dronning Maud Land. Norwegian-British-Swedish Antarctic Expedition, 1949-52. Scientific Results (Oslo, Norsk Polarinstitutt), Vol. 3 , A, p. I-37.

Swithinbank, C. W. M. I957[b]. Glaciology. I. The regime of the ice shelf at Maudheim as shown by stake measurements. Norwegian-British-Swedish Antarctic Expedition, 1949-52. Scientific Results (Oslo, Norsk Polarinstitutt), Vol. 3, B, p. 4I-75.

Swithinbank, C. W. M. 1958. Glaciology. I. The movement of the ice shelf at Maudheim. Norwegian-BritishSwedish Antarctic Expedition, 1949-52. Scientific Results (Oslo, Norsk Polarinstitutt), Vol. 3, C, p. 77-96.

Swithinbank, C. W. M. [1962.] Maudheim revisited: the morphology and regime of the ice shelf, r950-6o. Norsk Polarinstitutt. Arbok, 1960, p. 28-31.

Vyalov, S. S. 1958. Regularities of ice deformation (some results of laboratory researches). Union Géodésique et Géophysique Internationale. Association Internationale d'Hydrologie Scientifique. Symposium de Chamonix, 16 -24 sept. 1958, p. $383-91$.

Weertman, J. 1957. Deformation of floating ice shelves. Fournal of Glaciology, Vol. 3, No. 21, p. $3^{8-42 .}$ 
Zumberge, J. H. I964. Horizontal strain and absolute movement of the Ross Ice Shelf between Ross Island and Roosevelt Island, Antarctica, 1958-1963. (In Mellor, M., ed. Antarctic snow and ice studies. Washington, D.C., American Geophysical Union, p. 65-8r. (Antarctic Research Series, Vol. 2.))

Zumberge, J. H., and Swithinbank, C. W. M. 1962. The dynamics of ice shelves. American Geophysical Union. Geophysical Monograph No. 7, p. 197-208. 